\title{
Tropical peatlands and their conservation are important in the context of COVID-19 and potential future (zoonotic) disease pandemics
}

Mark E Harrison ${ }^{\text {Corresp., 1, 2, } 3 \text {, Lahiru S. Wijedasa }}{ }^{4,5}$, Lydia E S Cole ${ }^{6}$, Susan M Cheyne ${ }^{2,7,8}$, Shofwan Al Banna Choiruzzad $^{9,10}$, Liana Chua ${ }^{11}$, Greta C Dargie ${ }^{12}$, Corneille E N Ewango ${ }^{13}$, Euridice N Honorio Coronado ${ }^{14}$, Suspense A Ifo ${ }^{15}$, Muhammad Ali Imron ${ }^{16}$, Dianna Kopansky ${ }^{17}$, Trilianty Lestarisa ${ }^{18,19}$, Patrick J O'Reilly ${ }^{3}$, Julie Van Offelen ${ }^{20}$, Johannes Refisch ${ }^{21}$, Katherine Roucoux ${ }^{6}$, Jito Sugardjito ${ }^{22,23}$, Sara A Thornton ${ }^{2,3}$, Caroline Upton ${ }^{3}$, Susan Page 2,3

1 Centre for Ecology and Conservation, College of Life and Environmental Sciences, University of Exeter, Penryn, United Kingdom

2 Borneo Nature Foundation International, Penryn, United Kingdom, United Kingdom

3 School of Geography, Geology and the Environment, University of Leicester, Leicester, United Kingdom

4 Integrated Tropical Peatland Research Program (INTPREP), Environmental Research Institute, National University of Singapore, Singapore, Singapore

5 ConservationLinks Pvt Ltd, Singapore, Singapore

6 School of Geography and Sustainable Development, University of St. Andrews, St. Andrews, United Kingdom

7 Humanities and Social Sciences, Oxford Brookes University, Oxford, United Kingdom

8 IUCN SSC PSG Section on Small Apes, Oxford, United Kingdom

9 Department of International Relations, Universitas Indonesia, Depok, Indonesia

10 ASEAN Studies Center, Universitas Indonesia, Depok, Indonesia

11 Department of Social and Political Sciences, Brunel University, London, United Kingdom

12 School of Geography, University of Leeds, Leeds, United Kingdom

13 Faculty of Renewable Natural Resources Management / Faculty of Sciences, University of Kisangani, Kisangani, DR Congo

14 Instituto de Investigaciones de la Amazonía Peruana, Iquitos, Perú

15 Laboratoire de Géomatique et d'Ecologie Tropicale Appliquée, Département des Sciences et Vie de la Terre, Ecole Normale Supérieure, Université Marien Ngouabi, Brazzaville, Republic of Congo

16 Faculty of Forestry, Universitas Gadjah Mada, Yogyakarta, Indonesia

17 Global Peatlands Initiative, Ecosystems Division, United Nations Environment Programme, Nairobi, Kenya

18 Faculty of Medicine, Palangka Raya University, Palangka Raya, Kalteng, Indonesia

19 Doctoral Program of Public Health, Airlangga University, Surabaya, Indonesia

20 Independent Consultant, Nairobi, Kenya

21 Great Apes Survival Partnership, United Nations Environment Programme, Nairobi, Kenya

22 Centre for Sustainable Energy and Resources Management, Universitas Nasional, Jakarta, Indonesia

23 Faculty of Biology, Universitas Nasional, Jakarta, Indonesia

Corresponding Author: Mark E Harrison

Email address: m.e.harrison@exeter.ac.uk

The COVID-19 pandemic has caused global disruption, with the emergence of this and other pandemics having been linked to habitat encroachment and/or wildlife exploitation. High impacts of COVID-19 are apparent in some countries with large tropical peatland areas, some of which are relatively poorly resourced to tackle disease pandemics. Despite this, no previous investigation has considered tropical peatlands in the context of Peer] reviewing PDF | (2020:06:50176:1:1:NEW 10 Sep 2020) 
emerging infectious diseases (EIDs). Here, we review: (i) the potential for future EIDs arising from tropical peatlands; (ii) potential threats to tropical peatland conservation and local communities from COVID-19; and (iii) potential steps to help mitigate these risks. We find that high biodiversity in tropical peat-swamp forests, including presence of many potential vertebrate and invertebrate vectors, combined, in places, with high levels of habitat disruption and wildlife harvesting represent suitable conditions for potential zoonotic EID (re-)emergence. Although impossible to predict precisely, we identify numerous potential threats to tropical peatland conservation and local communities from the COVID-19 pandemic. This includes impacts on public health, with the potential for haze pollution from peatland fires to increase COVID-19 susceptibility a noted concern; and on local economies, livelihoods and food security, where impacts will likely be greater in remote communities with limited/no medical facilities that depend heavily on external trade. Research, training, education, conservation and restoration activities are also being affected, particularly those involving physical groupings and international travel, some of which may result in increased habitat encroachment, wildlife harvesting or fire, and may therefore precipitate longer-term negative impacts, including those relating to disease pandemics. We conclude that sustainable management of tropical peatlands and their wildlife is important for mitigating impacts of the COVID-19 pandemic, and reducing the potential for future zoonotic EID emergence and severity, thus strengthening arguments for their conservation and restoration. To support this, we list seven specific recommendations relating to sustainable management of tropical peatlands in the context of COVID-19/disease pandemics, plus mitigating the current impacts of COVID-19 and reducing potential future zoonotic EID risk in these localities. Our discussion and many of the issues raised should also be relevant for non-tropical peatland areas and in relation to other (pandemic-related) sudden socio-economic shocks that may occur in future. 
1 Tropical peatlands and their conservation

2 are important in the context of COVID-19

3 and potential future (zoonotic) disease

4 pandemics

5

6

7

8

9

10

11

12

13

14

15

16

17

18

19

20

21

22

23

24

25

26

27

28

29

30

31

32

33

34

35

36

37

38

39

40

Mark E. Harrison ${ }^{1,2,3}$, Lahiru S. Wijedasa ${ }^{4,5}$, Lydia E. S. Cole ${ }^{6}$, Susan M. Cheyne ${ }^{2,7,8}$, Shofwan Al Banna Choiruzzad ${ }^{9,10}$, Liana Chua ${ }^{11}$, Greta C. Dargie ${ }^{12}$, Corneille E.N. Ewango ${ }^{13}$, Euridice N. Honorio Coronado ${ }^{14}$, Suspense Averti Ifo ${ }^{15}$, Muhammad Ali Imron ${ }^{16}$, Dianna Kopansky ${ }^{17}$, Trilianty Lestarisa ${ }^{18,19}$, Patrick J. O'Reilly ${ }^{3}$, Julie Van Offelen ${ }^{20}$, Johannes Refisch ${ }^{21}$, Katherine Roucoux $^{6}$, Jito Sugardjito ${ }^{22,23}$, Sara A. Thornton ${ }^{2,3}$, Caroline Upton ${ }^{3}$, Susan Page ${ }^{2,3}$

1 Centre for Ecology and Conservation, College of Life and Environmental Sciences, University of Exeter, Penryn, UK

2 Borneo Nature Foundation International, Tremough Innovation Centre, Penryn, UK.

3 School of Geography, Geology and the Environment, University of Leicester, Leicester, UK.

$4 \quad$ Integrated Tropical Peatland Research Program (INTPREP), Environmental Research Institute, National University of Singapore, Singapore

5 ConservationLinks Pvt Ltd, Singapore

6 School of Geography and Sustainable Development, University of St Andrews, St Andrews, UK

7 Humanities and Social Sciences, Oxford Brookes University, Oxford, UK

8 IUCN SSC PSG Section on Small Apes, Oxford, UK

9 Department of International Relations, Universitas Indonesia, Depok, Indonesia

10 ASEAN Studies Center, Universitas Indonesia, Depok, Indonesia

11 Department of Social and Political Sciences, Brunel University, London, UK

12 School of Geography, University of Leeds, Leeds, UK

13 Faculty of Renewable Natural Resources Management / Faculty of Sciences, University of Kisangani, P.O. Box 2012, Kisangani, DR Congo

14 Instituto de Investigaciones de la Amazonía Peruana, Av. Abelardo Quiñones km 2.5, Iquitos, Perú

15 Laboratoire de Géomatique et d'Ecologie Tropicale Appliquée, Département des Sciences et Vie de la Terre, Ecole Normale Supérieure, Université Marien N'GOUABI BP 237, Brazzaville, Republic of Congo

16 Faculty of Forestry, Universitas Gadjah Mada, Yogyakarta, Indonesia

17 Global Peatlands Initiative, Ecosystems Division, United Nations Environment Programme, Nairobi, Kenya

18 Faculty of Medicine, Palangka Raya University, Palangka Raya, Indonesia

19 Doctoral Program of Public Health, Airlangga University, Surabaya, Indonesia 


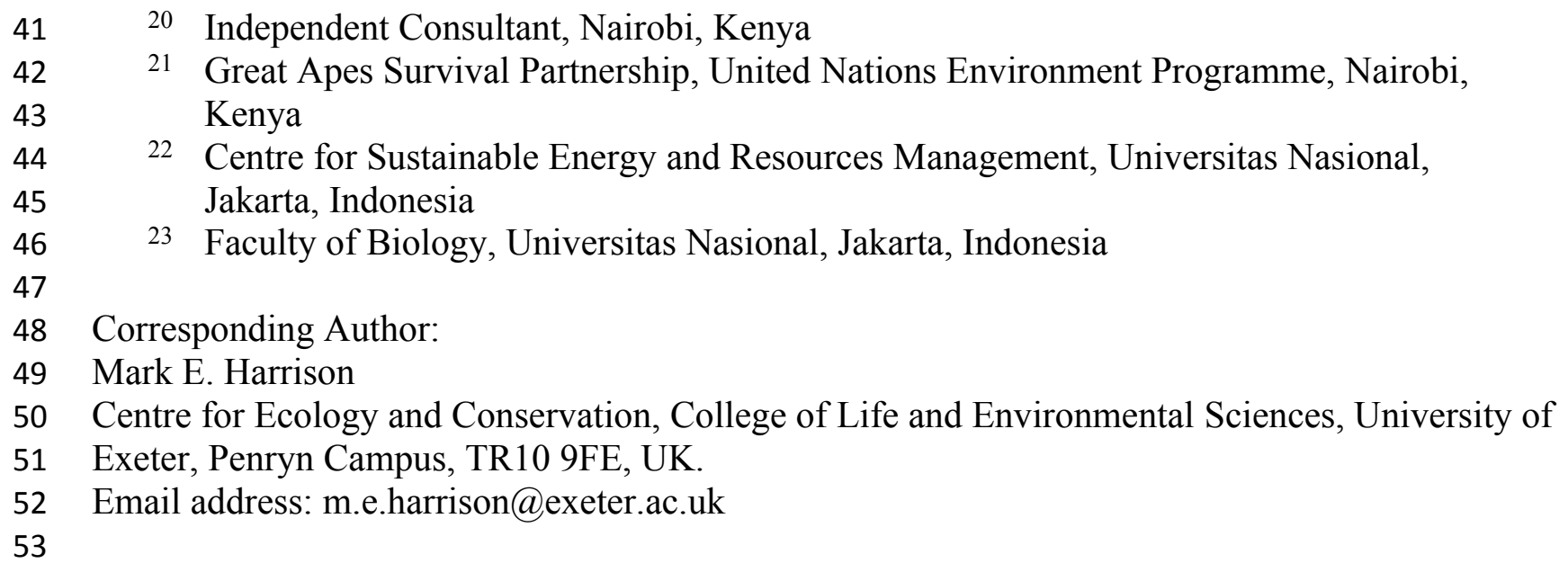


54

55

56

57

58

59

60

61

62

63

64

65

66

67

68

69

70

71

72

73

74

75

76

77

78

79

80

81

82

83

84

85

86

87

88

89

90

91

92

93

94

95

96

97

\section{Abstract}

The COVID-19 pandemic has caused global disruption, with the emergence of this and other pandemics having been linked to habitat encroachment and/or wildlife exploitation. High impacts of COVID-19 are apparent in some countries with large tropical peatland areas, some of which are relatively poorly resourced to tackle disease pandemics. Despite this, no previous investigation has considered tropical peatlands in the context of emerging infectious diseases (EIDs). Here, we review: (i) the potential for future EIDs arising from tropical peatlands; (ii) potential threats to tropical peatland conservation and local communities from COVID-19; and (iii) potential steps to help mitigate these risks. We find that high biodiversity in tropical peatswamp forests, including presence of many potential vertebrate and invertebrate vectors, combined, in places, with high levels of habitat disruption and wildlife harvesting represent suitable conditions for potential zoonotic EID (re-)emergence. Although impossible to predict precisely, we identify numerous potential threats to tropical peatland conservation and local communities from the COVID-19 pandemic. This includes impacts on public health, with the potential for haze pollution from peatland fires to increase COVID-19 susceptibility a noted concern; and on local economies, livelihoods and food security, where impacts will likely be greater in remote communities with limited/no medical facilities that depend heavily on external trade. Research, training, education, conservation and restoration activities are also being affected, particularly those involving physical groupings and international travel, some of which may result in increased habitat encroachment, wildlife harvesting or fire, and may therefore precipitate longer-term negative impacts, including those relating to disease pandemics. We conclude that sustainable management of tropical peatlands and their wildlife is important for mitigating impacts of the COVID-19 pandemic, and reducing the potential for future zoonotic EID emergence and severity, thus strengthening arguments for their conservation and restoration. To support this, we list seven specific recommendations relating to sustainable management of tropical peatlands in the context of COVID-19/disease pandemics, plus mitigating the current impacts of COVID-19 and reducing potential future zoonotic EID risk in these localities. Our discussion and many of the issues raised should also be relevant for non-tropical peatland areas and in relation to other (pandemic-related) sudden socio-economic shocks that may occur in future.

\section{Introduction}

The COVID-19 pandemic has caused unprecedented global disruption, at the time of writing infecting millions and killing hundreds of thousands of people across the globe (Dong, Du \& Gardner, 2020). These health impacts, plus lockdowns and other measures to control the pandemic, have resulted in reduced economic activity and job losses, leading to potentially the worst global recession since the Great Depression (IMF, 2020). While these global economic and social disruptions have had a positive, albeit likely temporary, impact on global carbon emissions (Le Quéré et al., 2020), negative outcomes are widely expected for biodiversity conservation, research (Corlett et al., 2020; Evans et al., 2020; Hockings et al., 2020; Lindsey et al., 2020), and indigenous communities (IUCN, 2020; UN/DESA, 2020; UN/EMRIP, 2020).

Peer) reviewing PDF | (2020:06:50176:1:1:NEW 10 Sep 2020) 
COVID-19 cases and deaths have been recorded for most tropical countries, with high numbers in some (Dong, Du \& Gardner, 2020), and with testing shortfalls likely partially accounting for low reported case numbers for some other tropical nations, particularly in Africa (Ditekemena, 2020; Nordling, 2020). Many tropical nations are low- or middle-income countries, with weaker health systems and fewer resources to tackle the pandemic, generating further concerns. Some of the countries with high infection and mortality rates also have large remaining areas of tropical peatland, including Brazil, Peru, Ecuador and Indonesia (Dong, Du \& Gardner, 2020; Page, Rieley \& Banks, 2011). While currently reporting relatively few cases, the Congo Basin contains the world's largest tropical peatland area (Dargie et al., 2017), is among the most poorly resourced to tackle disease pandemics in general (Oppenheim et al., 2019) and COVID-19 in particular (WB, 2020a), and the Democratic Republic of Congo (DRC) is projected to suffer a substantial number of cases and deaths (Cabore et al., 2020).

The importance of healthy tropical peatlands for carbon storage and emission mitigation, conserving biodiversity and providing ecosystem services for local communities is increasingly recognised (Baker et al., 2020; Crump, 2017; Dargie et al., 2017; Dommain et al., 2016; Hooijer et al., 2009; Husson et al., 2018; Page, Rieley \& Banks, 2011; Posa, Wijedasa \& Corlett, 2011), but to our knowledge no published study has specifically considered tropical peatlands and their inhabitants in the context of emerging infectious disease (EID), although some infectious disease studies have been conducted in tropical peatland areas (e.g., Vittor et al., 2006). Addressing this gap is important because ongoing land-use change is reducing tropical peat-swamp forest (TPSF) coverage, while bringing an increasing number of human communities in close contact with peatlands (Field, van der Werf \& Shen, 2009; Parish et al., 2008) and thus their biodiversity, although to date this has occurred far less in South American and African peatlands, compared to South-east Asia (Dargie et al., 2019; Roucoux et al., 2017). Such an assessment is made more urgent considering the ongoing COVID-19 pandemic and its potential impacts, and the global trend for increased EID event incidence (Jones et al., 2008). It is also relevant for understanding and reducing the potential for emergence of, and impacts arising from, any future EIDs in tropical peatland nations.

Our goals in this paper are thus to present a preliminary synthesis of: (i) the potential for future EID (re-)emergence from tropical peatlands; (ii) potential threats to tropical peatland conservation and local communities from the current COVID-19 pandemic; and (iii) potential steps to help mitigate these risks. These goals cover a very broad range of potential topic areas, ranging from local livelihoods and food security, to habitat conservation efforts and scientific research, among others. A summary illustrating some key features relating to (i) and (ii) is provided in Fig. 1. Although focused on tropical peatlands, many of the issues discussed and concerns raised will also be relevant to non-peatland areas in the tropics. This synthesis should thus be of interest to researchers, conservation/restoration/community project proponents, land managers and policy makers in the tropics, especially in but not restricted to peatland areas. While framed in the context of COVID-19, it is also pertinent to note that our discussion and many of the issues raised are in reality not uniquely linked to COVID-19, but rather relate more generally to (pandemic-related) sudden socio-economic shocks (e.g., economic recessions, border closures due to other causes, or extreme events related to climate change) that may occur in future. 
144

145

146

147

148

149

150

151

152

153

154

155

156

157

158

159

160

161

162

163

164

165

166

167

168

169

170

171

172

173

174

175

176

177

178

179

180

181

182

183

184

INSERT FIG. 1 AROUND HERE

\section{Survey Methodology}

We conducted a scoping review of relevant literature in relation to the above goals. First, we conducted a structured search of scientific databases using search terms related to these topics (Table S1). This approach reduces potential for bias in awareness among our author team, but yielded very few potentially relevant studies (total $n=6$, Table S2), owing to a lack of past studies concerning EIDs, including COVID-19, in the context of tropical peatlands. These results alone were insufficient to draw meaningful conclusions relating to any one of our goals, whereas conducting similarly structured database searches around every potential topic of relevance to EIDs/COVID-19 in the context of tropical peatlands would have been impractical, given the huge variety of potentially relevant topics relating to our goals, large number of countries containing tropical peatlands and the fact that these countries are not entirely covered in tropical peatlands, thus limiting potential to use individual tropical peatland nation names as search criteria. Consequently, we also conducted a less formally structured literature review, drawing on the subject knowledge, awareness of formal and informal literature sources, personal experiences and networks of our author team. In line with our scoping aims and very broad line of questioning, this did not employ strict inclusion and exclusion criteria, asides from excluding studies of no conceivable relevance to EIDs/COVID-19 and tropical peatlands. Such an approach allows us to draw relevant information from the many studies and reports of potential relevance that we were aware of that do not specifically concern EIDs/COVID-19 in the context of tropical peatlands and that did not therefore appear in our structured searches. The remainder of this manuscript is therefore focused on this much more informative less formally structured review, though findings from the structured search are integrated in relevant sections of the text.

To help ensure comprehensive coverage of the literature, and minimise geographic and subject bias in this review, our author team was developed to include natural and social scientists with substantial direct experience of, and familiarity with the literature in relation to, tropical peatland research in South-east Asia, Africa and South America (see, e.g., past reviews: Dargie et al., 2019; Harrison et al., 2020; Page \& Hooijer, 2016; Roucoux et al., 2017). While we attempt to provide context across all four continents on which tropical peatlands are found, we acknowledge some bias towards South-east Asia, for which a far greater volume of information is available. Where possible we draw upon peer-reviewed and other highly reputable sources (e.g., UN reports), but owing to the COVID-19 pandemic's recent emergence and consequent paucity of such literature relating specifically to it in the context of the issues considered, we also draw upon pre-prints and media reports where peer-reviewed sources are unavailable or just provide general (rather than COVID-19 specific) support for a statement. We attempt to indicate such cases clearly and verify these from multiple sources, while noting that this reflects the uncertainty and rapid evolution of the pandemic and associated public debate. 
185

186

187

188

189

190

191

192

193

194

195

196

197

198

199

200

201

202

203

204

205

206

207

208

209

210

211

212

213

214

215

216

217

218

219

220

221

222

223

224

225

226

227

228

229

\section{Are Tropical Peatlands a Potential Source Habitat for Disease Pandemics?}

Most EID events are dominated by zoonoses (60.3\%), with the majority of these $(71.8 \%)$ originating in wildlife, including Acquired Immunodeficiency Syndrome (AIDS), Severe Acute Respiratory virus (SARS), Middle East Respiratory Syndrome (MERS) and Ebola virus (Jones et al., 2008), plus the novel COVID-2019, an ongoing global pandemic as we write this paper (Li et al., 2020). In Africa, for example, 25 types of parasites, nine main types of viruses and eight types of bacteria have been reported as present in wild meat and communicable to humans (van Vliet et al., 2017). The joint-first reported case of Ebola in 1976 is from a peatland area (Yambuku, DRC: Muyembe-Tamfum et al., 2012), as is the most recent outbreak in May 2020 (Mbandaka, DRC: WHO, 2020c; Fig. 2), and the cradle of the HIV/AIDS pandemic is believed to be around Kinshasa, DRC, another area with extensive peatlands (Sharp \& Hahn, 2011; Worobey et al., 2008). The risk of zoonotic EID emergence is positively correlated with high human population density and wildlife host richness (Allen et al., 2017; Jones et al., 2008); wild animal harvesting and/or movement of animals or body parts, leading to increased contact between wildlife vectors and humans (Bengis et al., 2004; Johnson et al., 2020); biodiversity loss (Keesing et al., 2010); spread of non-indigenous vectors and pathogens; plus habitat encroachment, fragmentation and alteration (Allen et al., 2017; Johnson et al., 2020; Pongsiri et al., 2009).

\section{INSERT FIG. 2 AROUND HERE}

The natural habitat of tropical peatlands, tropical peat-swamp forest (TPSF), possesses a rich fauna and flora, including numerous vertebrate taxa known to represent zoonotic EID risk, such as bats, rodents, pangolins and primates (Husson et al., 2018; Inogwabini et al., 2012; Posa, Wijedasa \& Corlett, 2011). Indeed, previous studies on primates and small mammals in Southeast Asian TPSF areas have recorded numerous parasite species found in humans and that are of medical concern (Hilser, 2011; Hilser et al., 2014; Madinah et al., 2011; Madinah et al., 2011; Nurcahyo, Konstanzová \& Foitová, 2017), and surveys of bats from TPSF areas in Peru have detected high rates of Bartonella bacteria infection (Bai et al., 2012), suggesting potential for disease transmission from humans to wildlife and zoonotic transmission from wildlife to humans in TPSF areas. Studies conducted in non-TPSF areas on species that are also found in TPSF support this conclusion (e.g., chimpanzee Pan troglodytes deaths from human paramyxoviruses in Ivory Coast: Köndgen et al., 2008).

TPSF conversion, plus fire and wildlife harvesting brings more people into closer contact with peatland biodiversity. In South-east Asia, degradation, fragmentation and conversion of TPSF to agriculture has been particularly widespread, with the area of peatland in Malaysia, Sumatra and Kalimantan covered by TPSF declining from 76\% (11.9 Mha) in 1990 to $29 \%$ (4.6 Mha) in 2015 , with a concomitant increase from $11 \%$ (1.7Mha) to $50 \%$ (7.8Mha) of the area covered by agriculture over the same time period (Miettinen, Shi \& Liew, 2016). This near doubling of agricultural extent has been driven by small-scale farmers (43-44\%), plus industrial oil palm (39\%) and paper pulp (11-26\%) (Miettinen, Shi \& Liew, 2016; Wijedasa et al., 2018). Further forest habitat fragmentation is expected if all planned road and rail infrastructure development 
230 projects on Kalimantan proceed as proposed, with a projected reduction in landscape

231

232

233

234

235

236

237

238

239

240

241

242

243

244

245

246

247

248

249

250

251

252

253

254

255

256

257

258

259

260

261

262

263

264

265

266

267

268

269

270

271

272

273

274

275 connectivity from $89 \%$ to $55 \%$ (Alamgir et al., 2019).

Such threats are not limited to South-east Asia. For example, although there is currently limited encroachment into the TPSFs of the Peruvian Amazon from industrial agriculture and infrastructure development (Lilleskov et al., 2019), these threats are present and considerable (Baker et al., 2020; Roucoux et al., 2017), and could increase the likelihood of EID emergence from the Amazon in the near future (Ellwanger et al., 2020). Likewise, projected mining permits, gas and oil exploration, timber and palm oil concessions, associated road construction and changing rainfall patterns due to global warming pose potential risks to the relatively undisturbed TPSF of the Congo Basin and its wildlife (Dargie et al., 2019; Haensler, Saeed \& Jacob, 2013; Miles et al., 2017; Wich et al., 2014). In the Republic of Congo (RoC), health authority reports claim that several recent malaria infections appeared in swampy forests for the first time following opening of logging trails (Rédaction, 2020), highlighting the potential for increased EID risk should these peatlands experience greater future encroachment.

Patterns of human-wildlife contact and wild meat hunting in tropical peatlands provide further potential for disease spill-over events (during which a pathogen from one species moves into another) from wildlife to humans to occur. Human population density in tropical peatland areas is typically not high (e.g., Peru: Lilleskov et al., 2019; Congo Basin: Dargie et al., 2019), but some large population centres are found close to TPSF (e.g., Jambi and Palangka Raya, Indonesia; North and South Selangor, Malaysia; Iquitos, Peru; Fig. 2), and certain human activities increase contact between people and potential animal vectors in TPSF. Wildlife harvesting for consumption and trade is common in tropical forest nations (Fa, Currie \& Meeuwig, 2003; Nielsen et al., 2018), including in TPSF areas. For example, in Central Kalimantan, Indonesia, Pteropus vampyrus (Linn.) fruit bats are captured in TPSF areas and transported to local markets for sale as wild meat (Harrison et al., 2011). High contact levels between bats, hunters and vendors occur, with hunters and vendors frequently bitten and most bites drawing blood, raising concerns regarding potential zoonotic disease transmission (Harrison et al., 2011), though recent anecdotal observations suggest that local demand and trade has decreased as a likely result of the pandemic (R. Dwi et al., 2020, pers. comm.). Other species are commonly harvested for commercial trade in tropical peatland nations, often for sale in dense population areas, including turtles (Schoppe, 2009) and primates (Nijman et al., 2015) in Indonesia; plus pangolins and numerous other species from across South-east Asia (Nijman, 2010). Similar unsustainable hunting has been reported in the Congo Basin (Fa, Currie \& Meeuwig, 2003; Poulsen et al., 2009). In the Peruvian Amazon TPSF, tapirs (Tapirus terrestris, Linn.), primates, rodents and other mammals are commonly hunted by local communities (Schulz et al., 2019a). Although there is some wildlife export to local market centres (e.g. Iquitos: Bodmer \& Lozano, 2001; Mayor et al., 2019), most is consumed at a household level and constitutes an important protein source (Schulz et al., 2019a), providing higher potential to limit wildlife export from peatland areas than may be the case in South-east Asia and Africa.

High densities of domestic and semi-wild animals reared on peatlands could also serve as a direct or indirect zoonotic EID vector to humans. For instance, in Indonesia, over 1.8 million chickens are kept in the predominantly peatland municipality of Palangka Raya (BPS Palangka Raya, 2018), while large numbers of naturally cave-roosting edible-nest swiftlets (mostly

Peer) reviewing PDF | (2020:06:50176:1:1:NEW 10 Sep 2020) 
276

277

278

279

280

281

282

283

284

285

286

287

288

289

290

291

292

293

294

295

296

297

298

299

300

301

302

303

304

305

306

307

308

309

310

311

312

313

314

315

316

317

318

Aerodramus spp.) are reared in special buildings in many peatland areas, with most nests exported to China (Husson et al., 2018; Koon \& Cranbrook, 2014; Thorburn, 2014).

In summary, the combination of high native faunal diversity, habitat encroachment and fragmentation, plus trade in native and non-native fauna in many tropical peatland areas appears to represent a suitable set of conditions under which zoonotic EIDs could potentially (re-)emerge in future. Given that TPSFs represent the largest remaining blocks of lowland forest in some areas (e.g., lowland Borneo: Wijedasa et al., 2018; Congo Basin: Dargie et al., 2017; parts of the Amazon: Roucoux et al., 2017), attention should be paid to conserving and sustainably managing these TPSFs and their wildlife to reduce the likelihood of potential future zoonotic EID pandemics arising.

\section{What are the Potential Immediate Impacts of the COVID-19 Pandemic in Tropical Peatland Areas?}

The impacts of the COVID-19 pandemic will depend heavily on its length and severity, and evolving government and societal responses, which will vary between and potentially even within tropical peatland nations. This unpredictability notwithstanding, we nevertheless outline some areas of potential concern relating to tropical peatlands specifically, while referring readers to the more generic issues raised by Corlett et al. (2020), Evans et al. (2020) and Hockings et al. (2020), many of which will apply to tropical peatlands as much as to other habitats, and to any potential future pandemics causing similar levels of socio-economic disruptions to COVID-19. It is also pertinent to note that these issues occur on top of pre-existing challenges for tropical peatland conservation and sustainable management (see Dargie et al., 2019; Harrison et al., 2020; Roucoux et al., 2017 for reviews).

\section{Public Health and Potential Combined Impacts from Haze Pollution}

Disadvantaged populations are expected to be disproportionately affected by pandemics, further exacerbating existing social and economic inequalities (Lee, Rogers \& Braunack-Mayer, 2008; WHO, 2009). With the exception of Reunion, Brunei, Puerto Rico and Australia, which contain only small peatland areas, all tropical peatland nations listed by Page, Rieley \& Banks (2011) are classified as low or middle income (OECD, 2020), with many also being considered relatively under-prepared to cope with disease pandemics (Oppenheim et al., 2019). Tropical peatland communities are often relatively remote and (agricultural) conditions marginal, with lower access to public health and other services, no or poor medical insurance, fewer formal employment opportunities and higher poverty rates than non-peatland areas (e.g., Kalimantan: Medrilzam et al., 2014; Thornton, 2017; van Beukering et al., 2008; Wiseman et al., 2018; DRC: C. Ewango \& G. Dargie, pers. obs.; Peru: E. Honorio, pers. obs.; Fig. 3). The rural populations of several tropical peatland nations have disproportionate numbers of people with underlying health conditions and/or malnutrition (e.g., Kandala et al., 2011; Nair, Wares \& Sahu, 2010), and many do not have access to formal healthcare, or the running water, good sanitation and hygiene systems required to implement the recommended WASH approach to COVID-19 (WHO \& 
319

320

321

322

323

324

325

326

327

328

329

330

331

332

333

334

335

336

337

338

339

340

341

342

343

344

345

346

347

348

349

350

351

352

353

354

355

356

357

358

359

360

361

362

363

364

UNICEF, 2020). For example, in Central Kalimantan, less than $40 \%$ of people have access to improved sanitation (WHO, 2017) and the province tends to perform poorly in healthcare provision evaluations (Suparmi et al., 2018; Wiseman et al., 2018). Disseminating COVID-19 health guidance information will likely also be more difficult in rural tropical peatland areas with poor communications infrastructure, further reducing the probability that risk reduction behaviours will be followed. It is therefore possible that the health impacts of the COVID-19 pandemic may be relatively severe and/or prolonged in tropical peatland nations.

\section{INSERT FIG. 3 AROUND HERE}

While their remoteness and low population densities may reduce the potential for COVID-19 to reach and spread between some rural tropical peatland communities, evidence to support this supposition is limited, since many of these communities - like many others on resource frontiers - are deeply embedded in market relations (e.g., Li, 2014; Medrilzam et al., 2014) and local to international value chains bring them into regular contact with outsiders (Dove, 2011; Schreer, 2016). Even among those communities living relatively autonomously, there are still levels of contact with non-community actors, including NGOs, researchers, public agencies and commercial organisations. Indeed, media reports from the Americas and Africa indicate that COVID-19 has already spread into remote indigenous communities (Brito, 2020; Wallace, 2020). In DRC, this comes on top of existing Ebola and measles epidemics (Blomfield, 2020), and in Iquitos, Peru, on top of dengue fever and leptospirosis outbreaks (Collyns, 2020b). Once introduced, the possibility of COVID-19 cases going undetected and unreported, owing to a lack of testing, limited awareness plus an element of fatalism arising from the commonness of disease in such communities (e.g., Borneo: L. Chua, pers. obs.), combined with the important role that communal activities and high levels of social interaction play in many peatland communities, raises the risk of infection spreading. The more limited public health resources in rural tropical peatland areas means that the health impacts arising should an outbreak occur are potentially more serious than in less remote and more affluent communities. Furthermore, development and medical assistance in tropical peatland areas may be temporarily halted due to financial and organisational challenges (e.g., mobile medical teams in Peruvian Amazon: (Vine Trust, 2020). These considerations place an onus on businesses, governments, NGOs and researchers working with such communities to take measures to reduce the chances of introducing and spreading the disease between communities.

Given that elderly people are more vulnerable to COVID-19 (Zhou et al., 2020), one impact of outbreaks in tropical peatland areas may be a loss of traditional local knowledge regarding these ecosystems. Another important knock-on impact highlighted by the WHO is potential for disrupted responses to other major public health issues that may risk reversing gains made against these. This includes malaria and dengue fever, which are endemic in many tropical peatland areas and exhibit several symptoms similar to COVID-19 (PAHO, 2020; WHO, 2020d); and immunisations for diseases such as diphtheria, measles and polio (WHO, 2020a). In addition, co-infection of COVID-19 with other diseases and increased COVID-19 mortality rates in co-infected patients has been reported (Lansbury et al., 2020; Zhou et al., 2020), as has a case of co-infection of COVID-19 and Plasmodium vivax malaria (Sardar et al., 2020; following hospitalisation and discharge, the patient in this case tested negative for both diseases). Important questions therefore exist regarding the potential for (increased impacts from) COVID-19 co- 
365

366

367

368

369

370

371

372

373

374

375

376

377

378

379

380

381

382

383

384

385

386

387

388

389

390

391

392

393

394

395

396

397

398

399

400

401

402

403

404

405

406

407

408

409 infection in tropical peatland areas, especially for the most vulnerable members of these communities. Measures to tackle these pre-existing diseases must therefore continue to remain a priority in tropical peatland areas.

Tropical peatland degradation and drainage increase fire risk. In Indonesia, peatland fires and their associated haze (smoke pollution) now occur almost annually (Gaveau et al., 2014; Page \& Hooijer, 2016; Fig. 4), leading to high carbon emissions, forest and biodiversity losses, and major public health impacts from inhalation of the toxic haze (see Harrison et al., 2020; Page \& Hooijer, 2016; Uda, Hein \& Atmoko, 2019 for reviews). The haze contains high small particulate concentrations and several toxic compounds, including $\mathrm{CO}_{2}, \mathrm{CO}, \mathrm{CH}_{4}, \mathrm{NH}_{3}, \mathrm{HCN}, \mathrm{NO}_{\mathrm{X}}, \mathrm{OCS}$ and $\mathrm{HCl}$ (Stockwell et al., 2016). Haze exposure during the prenatal period has been linked to decreased adult height attainment (Tan-Soo \& Pattanayak, 2019), and short-term exposure during the severe 2015 fires is estimated to have caused 100,300 or more premature mortalities in Equatorial Asia (Koplitz et al., 2016; see also Crippa et al., 2016). This is important in light of recent reports that increased air pollution may elevate COVID-19 case numbers, hospital admissions and mortality (Cole et al., 2020; Conticini, Frediani \& Caro, 2020; Ogen, 2020; Wu et al., 2020), and has led to concerns being raised by both regional think tanks (Gan et al., 2020) and relevant experts in media reports regarding peatland fires and COVID-19 (Jong, 2020b; Listiyorini, 2020; Varkkey, 2020), though under COVID-19 lockdown conditions such impacts may be at least partially mitigated by general shutdowns of anthropogenic activities (Kanniah et al., 2020). In particular, in a pre-print article, Cole et al. (2020) and Wu et al. (2020) report that an increase in PM2.5 (small particulate matter) of just $1 \mu \mathrm{g} / \mathrm{m}^{3}$ is associated with a $8-16.6 \%$ increase in COVID-19 death rate, whereas in Central Kalimantan, PM2.5 levels have been reported to exceed 1,500 $\mu \mathrm{g} / \mathrm{m}^{3}$ during severe fire periods (Atwood et al., 2016) and average mean exposures between 2011-2015 have been estimated at $26 \mu \mathrm{g} / \mathrm{m}^{3}$, over double the recommended WHO exposure limit (Uda, Hein \& Atmoko, 2019). Similar findings were reported in relation to the impacts of air pollution on fatalities from the earlier SARS epidemic in China (Cui et al., 2003), suggesting that high levels of air pollution may increase vulnerability of populations exposed to haze from peatland fires to future pandemics. Observations that SARSCoV-2 RNA can be present on particulate matter (Setti et al., 2020), and suggestions that the ability of fine particulates, such as PM2.5, to penetrate deep inside the lungs and remain in the air for long periods of time (Frontera et al., 2020) lead to further concern that haze pollution from peat fires may increase COVID-19 transmission. Finally, some symptoms of haze exposure are also similar to those of COVID-19 (e.g., dry cough, weakness), which may lead to complications with regards to COVID-19 testing and case identification. While extensive tropical peatland fires are currently mainly limited to Indonesia (Dargie et al., 2019; Lilleskov et al., 2019), increasing pressure to develop African and South American peatlands could elevate their fire risks if preventative measures are not implemented (Roucoux et al., 2017), with consequent potential impacts on the susceptibility of their populations to future respiratory EID pandemics. Continuing and amplifying measures to avoid and control fires in tropical peatlands (Page \& Hooijer, 2016; Dohong et al., 2018; Wijedasa et al., 2018; Harrison et al., 2020) is therefore of heightened importance.

INSERT FIG. 4 AROUND HERE 
410

411

412

413

414

415

416

417

418

419

420

421

422

423

424

425

426

427

428

429

430

431

432

433

434

435

436

437

438

439

440

441

442

443

444

445

446

447

448

449

450

451

452

453

454

455

\section{Economy and Livelihoods}

The COVID-19 pandemic and associated response measures are likely to have deep and longlasting adverse global and local economic impacts, with the worst case scenario being that poverty alleviation achieved in recent decades might be reversed, earnings reduced and our ability to meet the UN Sustainable Development Goal of ending poverty by 2030 compromised (ASEAN, 2020; Lucas, 2020; Sumner, Hoy \& Ortiz-Juarez, 2020; WB, 2020b). Although tropical peatland communities are less likely to face the types of direct interruptions to livelihood resulting from strict lockdowns, adverse economic impacts linked to the pandemic may nevertheless have important consequences for them. Indeed, low incomes in many tropical peatland households, and weak social and food security safety nets in many tropical peatland countries (FAO et al., 2019), may make them particularly vulnerable. Anticipating the nature and the severity of these effects is complicated by the diversity of peatland communities and their livelihood heterogeneity (Jelsma et al., 2017). In Indonesia, for example, economic activities include self-employment in commodity tree crop, short-term vegetable crop and livestock production (especially chicken), swiftlet nest farming, hunting, fishing, gathering non-timber forest products, logging, artisanal mining, employment in construction and other industries, trading, remittances from family members employed elsewhere, and employment by government services and NGOs (Schreer, 2016; Thornton, 2017). The intensity of direct economic impacts arising from the COVID-19 pandemic are likely to be linked to the way communities are integrated into wider trade and resource allocation networks. Here we consider some of these potential impacts.

The anticipated global recession is expected to have a generally negative impact on agricultural prices, with prevalent low incomes in peatland areas likely to amplify the impact of price falls. Indeed, the UN and IUCN have flagged the expected negative impact of the COVID-19 pandemic on the livelihoods of remote indigenous groups and called for special measures to restore and support traditional indigenous economies (IUCN, 2020; UN/DESA, 2020; UN/EMRIP, 2020). Tropical peatland communities are commonly not food self-sufficient and tend to be close to poverty at the best of times (Wildayana \& Armanto, 2018). Global food shortages due to COVID-19 may have implications for the price of imported food, increasing pressure on these communities and potentially forcing some into poverty (as feared more generally by key international institutions: (Sánchez-Páramo, 2020; WFP, 2020). Small-scale settler communities cultivating short-lifecycle food crops and staples serving local markets are likely to be less adversely affected, because demand for their output is relatively inelastic and close market proximity means they are better placed to respond to changes in local demand by rapidly switching production. To date, prices of such crops are indeed remaining relatively stable (Lucas, 2020), although some increases are anticipated (e.g., Amanta \& Aprilianti, 2020). For such producers, the greater problem may be changes in the price of agricultural inputs (e.g., fertilisers) and other imported goods.

Producers of commodities such as palm oil, rubber and beef on tropical peatlands are likely to experience more severe adverse impacts due to falling prices resulting from changes in international demand. For example, the value of palm oil fell by over 20\% from December 2019 to April 2020 (Index Mundi, 2020), and declining palm oil export volumes and domestic consumption have already been noted in Indonesia (Sarkar, 2020), leading to reported concerns 
456

457

458

459

460

461

462

463

464

465

466

467

468

469

470

471

472

473

474

475

476

477

478

479

480

481

482

483

484

485

486

487

488

489

490

491

492

493

494

495

496

497

498

499

500

regarding lower demand and falling prices (Gan et al., 2020). Any sustained fall in palm oil price is likely to more severely impact peatland-based production, which is less productive than cultivation on mineral soil, and small-scale producers, for whom yields are typically lower and who will have less resources to sustain them through difficult periods (Euler et al., 2016; Sumarga et al., 2016). These problems are exacerbated by the long-term commitment and substantial investments that these crops require, which restrict the capacity of farmers to rapidly change to other crops, thus limiting their resilience. Prolonged low prices, combined with longstanding issues such as land titling, are thus likely to lead to increased hardship among these small-scale commodity producers, with previous commodity price falls being linked to increased poverty, mental health issues and suicide among small scale producers (Tyson, Varkkey \& Choiruzzad, 2018). Conversely, decisions of better resourced, larger plantation companies regarding expansion or contraction of operations will be more heavily influenced by predictions of the longer-term impact of the COVID-19 pandemic, rather than immediate price changes. Current thinking in the palm oil industry appears to be that, while the short-term impact may be significant, longer-term effects are uncertain, given the nature of the product and its market (Sarkar, 2020), reducing the likelihood of substantial longer-term reductions in oil palm expansion by large operators. These price changes may nevertheless mean that alternative economic and livelihood options may compete more favourably economically with palm oil in tropical peatland areas (cf. Wich et al., 2011), possibly encouraging their uptake. However, evidence of land holding in tropical peatlands strongly suggests that financial problems linked to poor revenues and limited capital may contribute to plot abandonment (Yusoff, Muharam \& Khairunniza-Bejo, 2017).

It is likely that many employed and casual workers in tropical peatland cities will lose their immediate income sources owing to lockdowns and other disruptions, leading to migration of people from cities to home communities, with media reports suggesting this may already be happening in Indonesia (Listori, 2020), Malaysia (Radhi, 2020) and Peru (Collyns, 2020a; E. N. Honorio Coronado, pers. obs.). There is concern that this 'returning home' may bring sources of infection to vulnerable communities, leading to media reports of the strict closure of some indigenous territories (Sierra Praeli, 2020). This situation may impose a triple strain on tropical peatland communities by increasing the risk of infection via returning community members, imposing additional burdens on household resources and depriving households of external income sources. Furthermore, during previous periods of economic instability in Indonesia, such as following the 1998 financial crash, illegal land uses increased, including illegal logging (EIATELAPAK, 1999), as people sought alternative economic means. Economic disruptions are also expected in communities dependent upon eco-tourism (Evans et al., 2020; Hockings et al., 2020; Lindsey et al., 2020). There is thus a risk that the financial burden caused by the COVID-19 pandemic could increase unlawful exploitation of natural resources (timber, wild animals), as well as increasing other marginal livelihood practices (e.g. artisanal mining).

\section{Food Security}

The UN World Food Programme has predicted that the COVID-19 pandemic will lead to over a quarter of a billion people suffering acute hunger by the end of 2020, owing to increased conflict, reduced aid and trade, price fluctuations and lost incomes (Anthem, 2020). Concerns have been 
501 raised that the pandemic is affecting all four pillars of food security (food availability,

502 utilisation/nutrient intake, stability and particularly food access) and is leading to forced cut-

503 backs in nutrient-rich non-staple foods towards starchy staples, with consequent long-term

504 adverse health impacts (Laborde et al., 2020). We have already suggested that, given existing

505 relatively high poverty levels and frequent lack of food self sufficiency, plus positions at the end

506 of long supply chains for many external commodities, tropical peatland communities may be

507 particularly vulnerable to food supply problems and price rises. Furthermore, while statutory and

508 NGO food assistance programmes are operating and good transport links exist in some tropical

509 peatland areas, these are designed to deal with relatively small numbers of clients and could be

510 quickly overwhelmed if demand increases dramatically, whilst other areas have poor assistance

511 infrastructure and poor, or often no, road access (e.g., Fig. 3). For indigenous communities, such

512 issues may be exacerbated by a common lack of visibility in public policy (UN, 2009). Ensuring

513 food security and the provision of food assistance to tropical peatland areas thus presents

514 logistical, organisational and political challenges, and development of more localised food

515 supply chains may therefore be favourable in post-pandemic responses (as recommended in a

516 general context by Pearson et al., 2020).

517

518

519

520

521

522

523

524

525

526

527

528

529

530

531

532

533

534

535

536

537

538

As previously mentioned, tropical peatland community livelihood strategies are often based on a range of economic activities, whose relative importance varies temporally. For example, rural communities in Borneo have for centuries been fairly entrepreneurial and responsive to changing global/regional trade patterns (Arenz et al., 2017; Dove, 2011). From their perspective, the COVID-19 pandemic may therefore not be viewed exceptionally, but rather as yet another development to which they must respond. Consequently, any potential loss of economic opportunities and reduced external demand for, or price of, locally produced commodities in such communities may lead to individuals reconsidering their livelihood strategies, resulting in changes in natural resource exploitation. For example, any price declines in swiftlet nests produced in Indonesian peatland areas following potential economic slowdowns in China (the main market), may lead swiftlet keepers to search for alternative incomes from harvesting forest resources. While such shifts may not necessarily result in increased pressure on natural resources, concern nevertheless appears warranted, as recent reviews suggest that increased overall local environmental resource pressures may be expected under conditions of rural economic hardship (Robinson, 2016) and that, where poverty exists, households are more likely to pursue economic activities that improve their family's short-term livelihoods, regardless of environmental impacts (South-east Asia: Douglas, 2006; Peru: Schulz et al., 2019b). From a positive perspective, any such changes may present an opportunity to work productively with affected communities to innovate and find more sustainable, locally rooted ways of responding to their needs.

Nevertheless, research suggests that experience of adverse shocks leads to increased risk aversion (Gloede, Menkhoff \& Waibel, 2015) and that communities may be less willing to engage in alternative "sustainable" livelihood activities if these are perceived to carry increased risks (Rodriguez et al., 2009). Perceived threats to health, income and food security related to COVID-19 may therefore reduce uptake or outcomes of revitalisation and community development activities in tropical peatland areas. Indeed, work in Indonesia has demonstrated that ecosystem restoration activities are unlikely to be adopted unless accompanied by assurances concerning food and income security (Carmenta \& Vira, 2018). 
547

548

549

550

551

552

553

554

555

556

557

558

559

560

561

562

563

564

565

566

567

568

569

570

571

572

573

574

575

576

577

578

579

580

581

582

583

584

585

586

587

588

589

590

591

The post-(peak) pandemic pressures governments face to "rescue the economy", may lead governments and companies in tropical peatland areas to reduce (or at least withhold attempting to improve) social and environmental standards (e.g., media reports: Carrington, 2020; Hurowitz, 2020), in an effort to reduce commodity prices and thus increase sales to rescue or expand industries such as palm oil. While evidence is currently limited, some media reports indicate that the pandemic may be employed to chip away at existing environmental measures, such as the EU's palm oil ban (Kobo, 2020). Such trends could be exacerbated if economic restrictions and priority shifts lead to reduced enforcement of environmental and social regulations concerning extractive industries, or reduced emphasis on conservation and restoration, in tropical peatland areas.

\section{Land Conflicts}

Land conflicts are one of the most important and complicated problems in land-use management in many countries with large peatland areas (Colchester, 2010; Colchester et al., 2007;

Nesadurai, 2013; Scullion et al., 2014). In Peru, 24\% of the estimated peatlands of the PastazaMarañon overlap with oil-extraction or exploration concessions, national reserves and territories of indigenous communities (Roucoux et al., 2017). In Indonesia, 807,178 ha are in land tenure conflict, with $73 \%$ of this contested land in the plantation sector (KPA, 2019). Increasing economic pressures and food insecurity associated with the COVID-19 pandemic may potentially aggravate this situation, with any increases in land tenure conflict likely to lead to increased peat fire incidence, given previously reported links (Medrilzam et al., 2014; Suyanto, 2007), and potentially therefore to further disenfranchisement and displacement of the poorest households and communities. This, in turn, may trigger further habitat encroachment and increased human-wildlife contact, whilst both food insecurity and haze pollution in degraded tropical peatland areas may increase COVID-19 impacts and susceptibility, as we have previously outlined. A glimpse of the complex and uneven effects that can result from such large-scale disruptions is found in Schreer's (2016) ethnography of a Central Kalimantan village's experiences and aspirations in the early- to mid-2010s. Here, the end of the logging boom - precipitated in by rapid governmental decentralisation - in the mid-2000s had highly variable effects in her fieldsite, with migrants and non-migrants reacting differently, and other industries and initiatives bringing in new opportunities, risks and land conflicts, as well as widespread disillusionment and resentment at various external parties (Schreer, 2016).

The return migration of casual and temporary workers from cities in to rural tropical peatland communities and the continued presence of migrant labour (working in industries disrupted by COVID-19), as noted above, constitutes a further factor that may exacerbate pressure on land resources and thus increase conflicts, as well as acting as a direct vector for disease transmission. Supporting local communities in and around tropical peatland areas to resolve land tenure conflicts and promote inclusive, sustainable community-led management will likely prove important in mitigating these risks surrounding land conflict issues.

\section{Unequal Community and Gender Impacts}

Peer) reviewing PDF | (2020:06:50176:1:1:NEW 10 Sep 2020) 
592 Importantly, any negative economic, social, and health impacts for communities will not occur in 593 a vacuum, and the social and ecological impacts of COVID-19 will affect different communities 594 and community members unequally. Regional inequalities, and differences in access to health 595 facilities between rural and urban areas, are likely to impact (efforts to curb) COVID-19 impacts. 596 For example, in Indonesia, COVID-19 testing rates in Java have only surpassed WHO minimum 597 recommendations in the capital, Jakarta (WHO, 2020d), and other provinces with large peatland 598 areas generally lag behind in terms of health facility availability and access (MoH RoI, 2019). 599 Furthermore, there is evidence that legal and policy frameworks support development patterns 600 that marginalise peatland communities, resulting in the neglect of their interests by policy makers 601 (McCarthy \& Robinson, 2016). The COVID-19 crisis may exacerbate these trends, contributing 602 to increased levels of economic (Payne \& Bradley, 2020) and intersectional inequality (Bowleg, 2020). It is being increasingly recognised that tropical peatland communities are not

\section{Research, Training and Education}

In addition, studies have highlighted how economic, food and health crises often put women in a more vulnerable position compared to men, despite shrinking options available for both genders (Pitkin \& Bedoya, 1997; Pollock \& Lin Aung, 2010). For example, previous studies on other diseases such as tuberculosis have demonstrated context-specific gender-related differences in the barriers to access diagnostic and treatment services, especially in developing countries (Krishnan et al., 2014), while the greater role of women as primary care givers may increase their probability of infection (Davies \& Bennet, 2016; Wenham et al., 2020). In line with this,international organisations have already highlighted the key role that women play in food provision in indigenous rural communities and the likely heightening of this and other burdens on women, including the loss of childcare and other supports services, plus surges in domestic violence, during the COVID-19 pandemic (FAO, 2020; UN, 2020; UN/DESA, 2020). For example, the closure of schools is likely to disproportionately increase the childcare burden on mothers and older daughters within families (de Paz et al., 2020). Recognising and accounting for such gender differences will be important for mitigating the impact of COVID-19 in tropical peatland areas. Related to this, care should also be taken in pursuing novel economic developments, such as the expansion of independent oil palm smallholdings, which may risk exacerbating or even producing new gender inequalities (Elmhirst et al. 2017; Julia \& White 2012) that may in turn compound gender inequalities relating to COVID-19.

The COVID-19 pandemic is significantly impacting field research globally, with travel restrictions and social distancing, plus (potential) reductions in research funding, leading to the adjustment, postponement or cancellation of many ongoing and planned field activities (Corlett et al., 2020; Evans et al., 2020; Lindsey et al., 2020). Among other impacts, research disruptions could potentially delay or prevent key output production (with possible knock-on effects on policy development), cause data gaps (particularly for long-term ecological data collection) and equipment supply issues. Social research, especially that involving bringing people together 
637 physically, will be particularly impacted (Corlett et al., 2020). For example, at the time of 638 writing, the Indonesian Ministry of Research and Technology has prohibited new foreign 639 researchers from entering and conducting research activities until the pandemic has ended 640 (RISTEK-BRIN, 2020). In DRC, the UKRI-funded CongoPeat project is continuing to operate 641 virtually but field activities and face-to-face initiatives and meetings have been paused, with field 642 researchers required to depart suddenly and leave collected samples behind, thus delaying or 643 potentially even risking completion of their analysis (C. E. N. Ewango, G. Dargie \& D.

644 Kopansky, pers. obs.). Media reports indicate that some indigenous communities have

645 effectively closed off to visitors to protect themselves from the potentially devastating impacts of 646 COVID-19 on their communities (Peruvian Amazon, including the peatland region of Loreto:

647 Sierra Praeli, 2020; Papua: Milko, 2020). Similar observations have also been made for remote 648 villages in Central and West Kalimantan, Sabah and Sarawak (L. Chua \& M. A. Imron, pers. obs.), with such measures representing a traditional mechanism among rural Borneo communities for protecting themselves from the spiritual and other effects of dangerous events like deaths or disease outbreaks (Chua, 2012). Even after the COVID-19 pandemic (peak), such communities may retain their wariness, remaining less welcoming or even hostile to outside researchers, who have an ethical obligation to ensure that they do not inadvertently transmit the disease to these communities. Research on great apes and other primates is also at high risk of disruption, as measures are put in place to prevent reverse zoonotic transmission of SARS-CoV2, given the perceived vulnerability of these species (Damas et al., 2020; Gillespie et al., 2020; IUCN SSC WHSG \& PSG SGA, 2020; Melin et al., 2020). This has led some to question whether all primate field research should be cancelled for 2020 (Reid, 2020), with others highlighting the potential negative impacts of such a move and the potential primate conservation and research opportunities that may arise from the pandemic (Lappan et al., 2020; Trivedy, 2020). Ultimately, the risks of any research in relation to the COVID-19 threat will need to be carefully balanced against the counter-risks of not conducting or restricting research in terms of addressing other important conservation and community wellbeing issues. From a positive perspective, some of these developments may facilitate the empowerment of local scientists and thus help strengthen in-country scientific research in tropical peatland areas.

Research and training meetings are being cancelled or postponed around the globe, including rescheduling of the International Peatland Congress from June 2020 to May 2021, which will negatively impact both networking opportunities for peat scientists and short-term income for the International Peatland Society. Disruptions to teaching, research and networking activities, and related publications, will potentially have reverberating impacts on the careers and (short-term) incomes of students and junior researchers, with possible overall negative impacts on future scientific expertise (Corlett et al., 2020). For example, Borneo Nature Foundation (BNF) and Universitas Gadjah Mada (UGM) had been developing plans for BNF to support selected UGM students to conduct research dissertations on tropical peatlands in 2020. These have now been converted to desk-based projects, which cannot provide students with vital first-hand perspectives of the tropical peatland environment. More widely, impacts are likely to be especially severe and potentially irreversible for students and researchers already facing (economic) disadvantages, acting to further entrench existing biases and low representation of black, Asian and minority ethnic (BAME) groups in environmental organisations (Taylor, 2015), and women in tropical peatland research (Thornton et al., 2019). Parents, and particularly mothers, are also likely to be disproportionately affected (Staniscuaski et al., 2020). Some 
683 positive responses are, however, already evident in tropical peatland nations, with for example

684 UGM instituting a series of online expert talks, BNF conducting live children's education

685 sessions through Facebook Live (BNF, 2020a) and some schools in remote areas of Kalimantan

686 without internet using radio broadcasts to deliver teaching during the pandemic (Jakarta Post,

687 2020).

688

689

690

There is also the risk that research and development funds will be redirected towards COVID-19related projects, increasing the difficulty of accessing funding for other research and

691 conservation priorities (Evans et al., 2020). Funding shortfalls for tropical peatland research may

692 lead to local research and other staff temporarily losing income tied to specific projects, or even redundancies of permanent staff. While some international NGOs may be able to furlough some

695

696 staff to receive government funding support, this is unlikely to be an option in most tropical peatland countries. In addition to negatively impacting local economies (tropical peatland research is often conducted in remote rural areas with limited economic opportunities), redundancies of permanent research staff would also represent a consequent loss in local research project capacity if staff move to work in other sectors, which may be difficult and require a long time to replace. On the plus side, prolonged international travel restrictions may help promote the role of local researchers in multi-national research projects, while also reducing the carbon footprint of research involving international flights. Whilst it may be possible to maintain communications and coordination of many ongoing projects using online communication tools, this may be limited by lack of or slow internet connections in more remote tropical peatland areas. Equipping remote communities with such communication infrastructure would help minimise this and other wider impacts resulting from reduced potential for outsider travel to these areas. While researchers may be able to help contribute some individual-based assistance (e.g., laptop provision, booster aerials), provided sufficient flexibility exists in research grant provisions, larger-scale upgrades in communications infrastructure would require in-country government support. Potential may also exist for international travel funds to be reallocated to support online learning or other training for local students and researchers, helping to build local capacity in the long term, although in the shorter-term international travel to undertake studentships and receive training may be curtailed.

\section{Conservation and Restoration}

In addition to potential funding impacts discussed in the previous section, field activity disruptions, delays and cancelations will likely detrimentally impact many tropical peatland conservation, restoration, community development and outreach projects (e.g., Indonesia: Gan et al., 2020). This is particularly so when activities are time sensitive (e.g., planting seedlings during periods of optimal peat water level), require continued maintenance (e.g., tending seedlings in nurseries that may otherwise die, requiring much time and funds to replace), or typically involve large teams or in-person gatherings. For example, BNF temporarily halted all its in-person childrens' education and other activities involving groups of people, including community development, sustainable livelihood and fire-fighting training (BNF, 2020b). Some organisations have initiated self-isolation protocols before and after field visits as a COVID-19 
727 which although potentially effective in relation to reducing transmission risk, may place

728 additional demands and stresses upon staff.

729

730

731

732

733

734

735

736

737

738

739

740

741

742

743

744

745

746

747

748

749

750

751

752

753

754

755

756

757

758

759

760

761

762

763

764

765

766

767

768

769

770

771

772
Halting dialogue with tropical peatland communities, who are frequently remote and have limited or no internet access, may lead to reduced uptake or failure of alternative livelihood development activities, if critical implementation periods are missed (e.g. a planting season), enthusiasm wanes, community members seek alternative opportunities and become tied to these, or if initiatives are incorrectly implemented and so fail because of reduced training provision, thus potentially decreasing local enthusiasm for such initiatives in future. Even activities that can be postponed may still suffer from negative impacts, if this means that calendar-based targets are not met, community engagement drops, or consequent additional damage occurs (e.g., dams to restore peatland hydrology are damaged owing to lack of project presence in the area). As noted in the previous section, equipping rural communities with improved communications infrastructure would help minimise such impacts.

As is the case more generally (Corlett et al., 2020; Evans et al., 2020; Hockings et al., 2020; Lindsey et al., 2020), TPSF encroachment, timber and wildlife harvesting is likely to increase if conservation agencies are less active or visible, or enforcement reduced, particularly if rural communities do increasingly fall back on exploiting natural resources owing to economic shock or food insecurity (see above). For example, media reports quoting conservation organisations have already indicated increased poaching in the Leuser Ecosystem, Sumatra, which includes TPSF areas (Hanafiah, 2020). Importantly, if work restrictions or funding shortfalls lead to reduced fire-fighting capabilities in degraded tropical peatland areas, this may result in increased fire incidence and severity, as highlighted by reputed researchers and institutions in media reports (Cannon, 2020; Taylor, 2020). Fire-fighting in South-east Asian peatlands is often undertaken by local community members or, in plantations, by company teams. In these situations, Moore et al. (2020) identify COVID-19 infection risks either from a home setting to fire teams and, given the difficulties in social distancing during fire-fighting, from the fire team back to the home and community. This could impact on the effectiveness of fire-fighting, as well as on individuals and their families. As noted above, any resulting increases in TPSF degradation, fragmentation, wildlife harvesting, or haze pollution will be expected to increase the immediate impacts of the COVID-19 pandemic and/or future potential for zoonotic EID emergence in tropical peatland areas.

As a result of the above, plus the potential for SARS-CoV-2 transmission to susceptible wildlife species, there is a risk of significant negative impacts on tropical peatland biodiversity. This is likely to be particularly important for peatland specialists and already threatened species. This includes, for example, the orangutan (Pongo spp.): the two species occurring on tropical peatland are Critically Endangered, with low and rapidly declining populations, have limited distribution on only one island each (Sumatra: P. abelii, Lesson; Borneo: P. pygmaeus, Linn.), have significant proportions of their populations in tropical peatland, are unable to persist in completely deforested landscapes and are at high risk from hunting owing to their slow reproductive rates (Utami-Atmoko et al., 2017). Orangutans and other non-human primates (Damas et al., 2020; Melin et al., 2020) are also potentially at risk of spill-over of the virus, including from asymptomatic human carriers, leading to recommendations for ape-based ecotourism, field research and non-essential habitat conservation activities to be reduced, and

Peer) reviewing PDF | (2020:06:50176:1:1:NEW 10 Sep 2020) 
773

774

775

776

777

778

779

780

781

782

impacting the activities of rescue, rehabilitation and release organisations (BOSF, 2020; Gillespie et al., 2020; IUCN SSC PSG SGA, 2020; IUCN SSC WHSG \& PSG SGA, 2020; Reid, 2020). The crisis thus increases the urgency to fully implement the IUCN best practice guidelines on ape tourism and health monitoring/disease control (Gillespie et al., 2020; IUCN SSC WHSG \& PSG SGA, 2020). While eco-tourism is not currently commonplace in tropical peatlands, disruptions to ape-based eco-tourism may potentially threaten the viability of ape/habitat conservation and livelihood initiatives in those tropical peatland areas relying heavily on this source of income, and result in shifts back towards more destructive economic activities (cf. Evans et al., 2020; Hockings et al., 2020).

\section{How Might COVID-19 Impact Future Tropical Peatland Conservation, and What Repercussions Might This Have in Relation to Disease Pandemics?}

Recent comprehensive reviews have highlighted the multiple, inter-linked threats and challenges already facing tropical peatland conservation and restoration, and provided suggestions to help tackle these (Dargie et al., 2019; Harrison et al., 2020; Roucoux et al., 2017). The additional short- to medium-term considerations arising in the context of the COVID-19 pandemic that we outline above may not all come to light, may create only short-term issues if the pandemic proves to be relatively short lived and recovery is relatively rapid, or may create longer-term changes if the pandemic is long-lasting or creates irreversible shifts. The severity and duration of impacts experienced will inevitably also vary between and within tropical peatland nations. We cannot therefore provide firm predictions regarding longer-term impacts of the pandemic on tropical peatlands and their communities, and consequently on changes in the potential of tropical peatlands to act as a source of future zoonotic EID pandemics. This caveat notwithstanding, we highlight some potential longer-term changes that may be important for policy makers, scientists and other tropical peatland stakeholders to consider going forward.

Some tropical peatland nations have already indicated that development projects will be paused or cancelled, and that economic growth may be prioritised above sustainability concerns in postpandemic recovery phases, which could have long-term repercussions. For example, media reports indicate that Indonesia's planned capital city relocation may be postponed owing to the pandemic (Demetriadi, 2020; Gokkon, 2020), whereas Padat Karya (Labour Intensive) government projects involving large numbers of local community members are still proceeding and being prioritised as an attempt to mitigate the economic impacts of the crisis (Iskandar, 2020; Widodo, 2020), as are 89 major infrastructure development projects, including potential development of large peatland areas for food production in Central Kalimantan with the goal to improve food security (Jong, 2020a). A history of prioritising economic growth over public health in the context of haze from peatland fires has been suggested in Malaysia (Varkkey \& Copeland, 2020), while some recent media reports indicate that Indonesia will prioritise economic growth following the pandemic, with the consequence that emission reduction targets will not be increased (Jong, 2020c) and environmental protections potentially rolled back (Jong, 2020d). In Peru, the largest threat is the (re-)activation of regional economies to promote 
816 agricultural development (E1 Peruano, 2020), which with the current lack of any documents to 817 guide land use planning, may increase deforestation and access to remote forests (e.g. potential road construction that will affect peatlands in Loreto: Baker et al., 2020).

The race to return to economic growth and stability could also drive increased fossil fuel extraction. This is a risk in the Congo Basin (Dargie et al., 2019; Miles et al., 2017) and Peruvian Amazon (Lilleskov et al., 2019), where many oil concessions coincide with peatland areas. In Peru, oil extraction and transportation has led to many spills from poorly maintained pipes that have often been slow to be remediated (e.g., Rodríguez Mega, 2016). Expanding oil exploration and bringing new concessions into production involves infrastructure creation, clearing seismic survey lines, and building access roads and pipelines (Roucoux et al., 2017), typically causing habitat loss and degradation (Laurance, Goosem \& Laurance, 2009; Mäki, Kalliola \& Vuorinen, 2001). We note, however, that conversely and at least in the short-term, an alternative outcome of the pandemic could be lower global oil demand and production through at least 2020 (OGJ Editors, 2020), which may result in oil exploration becoming a lower immediate priority. Indeed, it has been indicated by the Ministry of Environment and Tourism that oil exploration in RoC peatland areas will not proceed in accordance with the country's international climate commitments (Arlette Soudan-Nonault, 2020, pers. comm.; see also Weston, 2020).

Concerns have been raised regarding the intersection of the COVID-19 outbreak and public health responses with the ongoing increase in climate hazards associated with climate change (Phillips et al., 2020). Tropical peatlands are vulnerable to climate change, which will likely result in increased drought frequency, duration and/or severity, with consequent peat water table lowering, and increased peat oxidation and fire incidence, as already seen extensively in Southeast Asia (Turetsky et al., 2015). There thus exists a risk of a positive-feedback loop development (cf. Harrison et al., 2020), whereby any decisions or events related to the pandemic that lead to increased peatland degradation and fire also then lead to further carbon emissions and peatland degradation, thus increasing future fire prevalence and the various negative impacts associated with this, including in relation to COVID-19 and potential future disease pandemics.

While peatland rewetting and revegetation may help mitigate some impacts of potential increases in the areas of degraded and burned peatland, these processes are unavoidably slow in nature, with peat burned in a single fire event taking potentially hundreds of years to re-form, generating concerns regarding the political tractability of some tropical peatland restoration goals (Harrison et al., 2020). Coupled with the existing large areas of degraded peatland already requiring restoration, particularly in South-east Asia, any potential increase in the extent of degraded and burned peatland as an indirect consequence of the COVID-19 pandemic would be expected to have long-term negative repercussions for tropical peatland management, community livelihoods, public health, carbon emissions and biodiversity. Reversing such changes, and enhancing the sustainability of tropical peatland management in general, may also become more challenging in the foreseeable future if, as discussed above, the current pandemic leads to loss of skilled, in-country peatland scientists and conservationists who would take time to replace. Any future pandemics may obviously exacerbate this. 
Our review indicates that sustainable management and conservation of tropical peatlands is important for mitigating the impacts of the current COVID-19 pandemic, while avoiding further encroachment into these ecosystems and intensive harvesting of their wildlife could reduce the potential for future zoonotic EID emergence and severity (summarised in Fig 1.). Importantly, because many of the potential impacts identified in relation to COVID-19 arise through socioeconomic disruptions relating to our response to the pandemic, rather than unique characteristics of the SARS-CoV-2 virus itself, this conclusion should be applicable more widely to pandemic situations and similar sudden socio-economic shocks. To our knowledge, this link between tropical peatland ecosystems and zoonotic EIDs has not been specifically noted previously and this therefore represents an important finding in terms of our understanding of the benefits that these ecosystems provide, thus strengthening the argument for their conservation and sustainable use. In addition, and recognising that our assessment is both preliminary and likely incomplete owing to the recent emergence and rapid evolution of the COVID-19 pandemic, we highlight the potential additional threats and challenges towards sustainable management of tropical peatlands and their wildlife posed by this pandemic, and the potential knock-on effects of these for tropical peatland conservation and local communities going forward.

These conclusions support and strengthen previous recommendations regarding the sustainable management of tropical peatlands, including regarding hydrological functions, fire prevention, avoiding encroachment and habitat fragmentation, plus maintaining and where necessary restoring healthy peatland ecosystems that support diverse biological communities, sequester carbon and provide socio-economic benefits to local communities (see, e.g., Dargie et al., 2019; Dohong, Abdul Aziz \& Dargusch, 2018; Graham, Giesen \& Page, 2017; Harrison et al., 2020; Mizuno, Fujita \& Kawai, 2016; Roucoux et al., 2017; Schulz et al., 2019a; Schulz et al., 2019b; Wijedasa \& al., 2018 and references therein for detailed recommendations). They also support previous recommendations to carefully manage terrestrial wildlife harvesting in and trade from tropical peatland areas (Bodmer \& Lozano, 2001; Harrison et al., 2011) and more generally (e.g., Corlett, 2007; Harrison et al., 2016). Further to these generic recommendations, we offer the following specific suggestions for researchers and practitioners relating to tropical peatland sustainable management, COVID-19 and potential future zoonotic EIDs:

1. Field projects should support frontline team members to reduce their COVID-19 exposure risk and, thus, the risk of them infecting other community members and of work being impacted through worker infection. In addition to ensuring and facilitating adherence to current government and WHO guidelines, specific recommendations have been proposed for fire-fighters (Moore et al., 2020), and work with great apes (IUCN SSC WHSG \& PSG SGA, 2020) and in their habitats (IUCN PSG SGA, 2020). Development of similar specific guidelines for other sectors relating to tropical peatland management could be beneficial.

2. All actors should support local communities in and around tropical peatland areas to resolve land tenure conflicts and promote sustainable community-led management (Blackman et al., 2017; Santika et al., 2017), facilitate locally-derived sustainable economy development (Pearson et al., 2020), and prevent external users from unsustainably exploiting these ecosystems. This includes encouraging, and where necessary opening up new, discussions regarding the relationships between use of and encroachment into tropical peatlands, 
commercial vs. subsistence wildlife harvesting, and zoonotic EID risk, and considering these holistically in the context of community wellbeing and aspirations (cf. Kavousi et al., 2020). It should also include re-orientating discussions, from conservation and development organisations approaching with a perspective of "how can we help them" to an approach of "we're all in this together, so what can we each bring to the table to help?". Such reorientations should ideally be informed by fresh social research on how communities' lives, relations and experiences have been impacted by COVID-19, as these are unlikely to simply revert to a pre-pandemic "normal".

3. The peatland research community should rethink approaches to research in at-risk communities, to potentially incorporate more remote and online working, plus enhanced roles for local research teams. This may require re-appraising how likely increasingly limited research resources are distributed, and particularly supporting local research capacity development and local researcher empowerment within international collaborations. Incorporating and centering local knowledge and priorities from the outset has the additional benefit of increasing the success of conservation and development interventions (Mistry \& Berardi, 2016). COVID-19 has forced increased use of online communications tools and we hope this can help foster new patterns of international collaboration that further empower local researchers. See Lupton (2020) for an extensive list of potential approaches to reducing COVID-19 risk during social science fieldwork.

4. Wherever possible and working within all relevant government and sector COVID-19 guidelines, research, conservation and community projects should continue collection of long-term monitoring data and initiate repeat data collection to provide before-and-after comparisons, in order to help assess the impacts of the COVID-19 pandemic in relation to the issues discussed in this paper. This may include, for example, patrol team or satellite data monitoring to assess if forest incursions or fire incidence have increased, or community livelihood data to assess if livelihood choices have changed and if/how this has impacted local wellbeing. It should also include collecting baseline human and wildlife community health information to better understand, monitor and thus mitigate zoonotic EID risk in tropical peatland areas.

5. Policy makers in tropical peatland areas should ensure that their policy decisions do not amplify the risks of the COVID-19 or potential future pandemics. In particular, any weakening of environmental and social standards and regulations relating to tropical peatlands should be avoided (see also Evers et al., 2017; Wijedasa et al., 2017). Instead, we recommend development and implementation of a "One Health / Ecohealth" approach in tropical peatland nations, that recognises and supports the complex, mutually-beneficial interconnections among the health of people, animals, plants and our shared environment (El Zowalaty \& Järhult, 2020; Hockings et al., 2020; Roger et al., 2016; UNEP \& ILRI, 2020). We further recommend strengthening communications infrastructure in (remote) tropical peatland areas, to help minimise any impacts of reduced travel or on-the-ground activities in these areas.

6. Funders should exercise maximum possible flexibility to tropical peatland research, conservation and community projects impacted by the COVID-19 pandemic, including regarding achieving deliverable targets and deadlines, where possible offering additional support to maintain local staff employment during periods of enforced down time instead of offering zero-cost funding extensions, and not penalising unavoidable "failures" by current projects in future funding application rounds. This will be important in minimising potential 
952

953

954

955

956

957

958

959

960

961

962

963

964

965

966

967

968

969

970

971

972

973

974

975

976

977

978

979

980

981

982

983

984

985

986

987

988

989

990

991

992

993

994

project closures, plus staff redundancies or lost income, and associated risk of loss of expertise. Opportunities to diversify revenue sources to increase the resilience of conservation efforts should also be explored (Lindsey et al., 2020).

7. All actors should recognise the role that tropical peatlands, their conservation, sustainable management and restoration will play in both the current COVID-19 pandemic and in the potential for future zoonotic EID emergence; and actively promote this message in fundraising, education, outreach, community and government engagement, while taking care to tailor messages and associated recommendations appropriately to local audiences (Chua, 2020; Kavousi et al., 2020; MacFarlane \& Rocha, 2020; see also Charania \& Tsuji, 2012; Chua et al., 2020).

As is the case more generally (e.g., Corlett et al., 2020; Evans et al., 2020; Hockings et al., 2020; UN/DESA, 2020; UN/EMRIP, 2020; UNEP \& ILRI, 2020), our review indicates that the relationships and reciprocal impacts between tropical peatland ecosystems and communities, COVID-19 and disease pandemics are inter-linked, multi-faceted, and likely to vary over both space and time. This adds an extra pandemic-related dimension to the increasingly complex picture that is emerging regarding the challenges and opportunities for conservation and sustainable management of tropical peatlands (Dargie et al., 2019; Harrison et al., 2020; Roucoux et al., 2017). At the same time, this also suggests that potential for win-win solutions exists to simultaneously address the challenges identified herein relating to COVID-19 and disease pandemics in tropical peatland areas, alongside the previously identified challenges facing these ecosystems and their resident human communities. This is particularly pertinent in light of recent analyses estimating that global pandemic prevention costs associated with reducing deforestation, wildlife trade and farmed animal spill-over, and early zoonotic disease detection and control over the course of ten years is equivalent to only about $2 \%$ of the costs of the COVID-19 pandemic (Dobson et al., 2020). Moving beyond these conclusions linked to our review, and while we hope that the COVID-19 pandemic is rapidly mitigated and thus many of the potential issues discussed in this paper fail to (fully) materialise, we nevertheless trust that our consideration of these issues and recommendations provided helps improve our ability to anticipate and prevent potential negative impacts that may arise from the pandemic. In addition, and regardless of the pandemic, we contend that it helps to foster the inter-connected thinking that will be required to ensure the future health and wellbeing of tropical peatlands and their human communities alike.

\section{Acknowledgements}

We thank our respective institutions for their support, Stuart Smith and Nur Estya Binte Rahman for discussions regarding literature reviews, and the many colleagues and tropical peatland communities that have engaged in fruitful discussions over the years and thus contributed towards our thinking in relation to the topics discussed in this paper. We are grateful to the Editor, Valéria Kaminski and one anonymous reviewer for constructive comments that helped improve the manuscript.

Peer) reviewing PDF | (2020:06:50176:1:1:NEW 10 Sep 2020) 
995

996

997

998

999

1000

1001

1002

1003

1004

1005

1006

1007

1008

1009

1010

1011

1012

1013

1014

1015

1016

1017

1018

1019

1020

1021

1022

1023

1024

1025

1026

1027

1028

1029

1030

1031

1032

1033

1034

1035

1036

1037

1038

1039

\section{References}

Alamgir M, Campbell MJ, Sloan S, Suhardiman A, Supriatna J, Laurance WF. 2019. High-risk infrastructure projects pose imminent threats to forests in Indonesian Borneo. Scientific Reports 9:140. DOI: 10.1038/s41598-018-36594-8

Allen T, Murray KA, Zambrana-Torrelio C, Morse SS, Rondinini C, Di Marco M, Breit N, Olival KJ, Daszak P. 2017. Global hotspots and correlates of emerging zoonotic diseases. Nature Communications 8:1124. DOI: 10.1038/s41467-017-00923-8

Amanta F, Aprilianti I. 2020. Policy Briefing no. 1. Indonesian Food Trade Policy During Covid-19. Jakarta, Indonesia: Centre for Indonesian Policy Studies. https://repository.cips-indonesia.org/media/309123-indonesian-food-trade-policy-duringcovi-7dd48951.pdf

Anthem P. 2020. Risk of hunger pandemic as coronavirus set to almost double acute hunger by end of 2020 World Food Programme Insight. 16 April 2020. https://insight.wfp.org/covid-19-will-almost-double-people-in-acute-hunger-by-end-of2020-59df0c4a8072

Arenz C, Haug M, Seitz S, Venz O. 2017. Continuity Under Change in Dayak Societies. Springer VS.

ASEAN. 2020. Economic Impact of COVID-19 Outbreak on ASEAN. Analysis and Monitoring on Finance and Socio-Economic Issues Division, ASEAN Integration Monitoring Directorate, ASEAN Secretariat. https://asean.org/storage/2020/04/ASEAN-Policy-BriefApril-2020 FINAL.pdf

Atwood EC, Englhart S, Lorenz E, Halle W, Wiedemann W, Siegert F. 2016. Detection and characterization of low temperature peat fires during the 2015 fire catastrophe in Indonesia using a new high-sensitivity fire monitoring satellite sensor (FireBird). PLoS One 11:e0159410. DOI: 10.1371/journal.pone.0159410

Bai Y, Recuenco S, Gilbert AT, Osikowicz LM, Gómez J, Rupprecht C, Kosoy MY. 2012. Prevalence and diversity of Bartonella spp. in bats in Peru. The American Journal of Tropical Medicine and Hygiene 87:518-523. DOI: 10.4269/ajtmh.2012.12-0097

Baker T, Del Castillo Torres D, Honorio Coronado E, Lawson I, Martín Brañas M, Montoya M, Roucoux K. 2020. The challenges for achieving conservation and sustainable development within the wetlands of the Pastaza - Marañon basin, Peru. In: Chirif Tirado A, ed. Peru: Deforestation in Times of Climate Change. Lima, Peru: IWGIA, 155-174.

Bengis RG, Leighton FA, Fischer JR, Artois M, Mörner T, Tate CM. 2004. The role of wildlife in emerging and re-emerging zoonoses. Revue Scientifique et Technique (International Office of Epizootics) 23:497-511.

Blackman A, Corral L, Lima ES, Asner GP. 2017. Titling indigenous communities protects forests in the Peruvian Amazon. Proceedings of the National Academy of Sciences 114:4123-4128. DOI: 10.1073/pnas.1603290114

Blomfield A. 2020. First Ebola, then measles, not Covid-19: Congo faces three simultaneous medical emergencies. 27 April 2020. https:/www.telegraph.co.uk/global-health/scienceand-disease/first-ebola-measles-now-covid-19-congo-faces-three-simultaneous/

BNF. 2020a. Jungle Explorers. Borneo Nature Foundation. 30 April 2020. https://www.facebook.com/watch/live/?v=1461107384091191\&ref=watch permalink 
1040

1041

1042

1043

1044

1045

1046

1047

1048

1049

1050

1051

1052

1053

1054

1055

1056

1057

1058

1059

1060

1061

1062

1063

1064

1065

1066

1067

1068

1069

1070

1071

1072

1073

1074

1075

1076

1077

1078

1079

1080

1081

1082

1083

1084

1085

BNF. 2020b. Statement by Borneo Nature Foundation concerning the CoVID-19 virus pandemic. Borneo Nature Foundation. 26 March 2020.

http://www.borneonaturefoundation.org/en/news/statement-by-borneo-nature-foundationconcerning-the-covid-19-virus-pandemic/

Bodmer RE, Lozano EP. 2001. Rural development and sustainable wildlife use in Peru. Conservation Biology 15:1163-1170. DOI: 10.1046/j.1523-1739.2001.0150041163.x

BOSF. 2020. BOSF Official Statement - COVID-19. Borneo Orangutan Survival Foundation. (accessed 4 May 2020). http://orangutan.or.id/bosf-official-statement-covid-19/

Bowleg L. 2020. We're not all in this together: On COVID-19, intersectionality, and structural inequality. American Journal of Public Health 110:917-917. DOI:

10.2105/AJPH.2020.305766

BPS Palangka Raya. 2018. Palangka Raya Municipality in Figures: 2018. Palangka Raya, Indonesia: BPS-Statistics of Palangka Raya Municipality.

Brito C. 2020. 15-year-old boy from Amazon tribe dies of coronavirus. CBS News. 10 April 2020. https://www.cbsnews.com/news/amazon-yanomami-tribe-15-year-old-boy-diescoronavirus-covid-19/

Cabore JW, Karamagi HC, Kipruto H, Asamani JA, Droti B, Seydi ABW, Titi-Ofei R, Impouma B, Yao M, Yoti Z, Zawaira F, Tumusiime P, Talisuna A, Kasolo FC, Moeti MR. 2020. The potential effects of widespread community transmission of SARS-CoV-2 infection in the World Health Organization African Region: a predictive model. BMJ Global Health 5:e002647. DOI: 10.1136/bmjgh-2020-002647

Cannon JC. 2020. COVID-19 and rainforest fires set up potential public health crisis. Mongabay. 18 June 2020. https://news.mongabay.com/2020/06/covid-19-and-rainforest-fires-set-uppotential-public-health-crisis/

Carmenta R, Vira B. 2018. Integration for restoration: Reflecting on lessons learned from the silos of the past. In: Mansourian S, Parrotta J, eds. Forest Landscape Restoration: Integrated Approaches to Support Effective Implementation. London: Routledge, 32-52.

Carrington D. 2020. Polluter bailouts and lobbying during Covid-19 pandemic. The Guardian . 17 April 2020. https://www.theguardian.com/environment/2020/apr/17/polluter-bailoutsand-lobbying-during-covid-19-pandemic

Charania NA, Tsuji LJS. 2012. A community-based participatory approach and engagement process creates culturally appropriate and community informed pandemic plans after the 2009 H1N1 influenza pandemic: remote and isolated First Nations communities of subarctic Ontario, Canada. BMC Public Health 12:268. DOI: 10.1186/1471-2458-12-268

Chua L. 2012. The Christianity of Culture: Conversion, Ethnic Citizenship, and the Matter of Religion in Malaysian Borneo. New York: Palgrave Macmillan.

Chua L. 2020. Message, medium, messenger: Communicating COVID-19 in rural Borneo. POKOK. 14 April 2020. https://pokokborneo.wordpress.com/2020/04/14/messagemedium-messenger-communicating-covid-19-in-rural-borneo/

Chua L, Harrison ME, Fair H, Milne S, Palmer A, Rubis J, Thung P, Wich S, Büscher B, Cheyne SM, Puri RK, Schreer V, Stępień A, Meijaard E. 2020. Conservation and the social sciences: Beyond critique and co-optation. A case study from orangutan conservation. People and Nature 2:42-60. DOI: 10.1002/pan3.10072

Colchester M. 2010. Palm Oil and Indigenous Peoples in Southeast Asia: Land Acquisition, Human Rights Violations and Indigenous Peoples on the Palm Oil Frontier. Moreton-inMarsh and Rome: Forest Peoples Programme and International Land Coalition.

Peer) reviewing PDF | (2020:06:50176:1:1:NEW 10 Sep 2020) 
1086

1087

1088

1089

1090

1091

1092

1093

1094

1095

1096

1097

1098

1099

1100

1101

1102

1103

1104

1105

1106

1107

1108

1109

1110

1111

1112

1113

1114

1115

1116

1117

1118

1119

1120

1121

1122

1123

1124

1125

1126

1127

1128

1129

1130

1131

Colchester M, Wee AP, Wong MC, Jalong T. 2007. Land is Life: Land Rights and Oil Palm Development in Sarawak. . Moreton-in-Marsh, England and Bogor, Indonesia: Forest Peoples Programme and Perkumpulan Sawit Watch.

Cole MA, Ozgen C, Strobl E. 2020. Air pollution exposure and Covid-19 in Dutch Municipalities. Environmental and Resource Economics. DOI: 10.1007/s10640-020$00491-4$

Collyns D. 2020a. Peru: riot police block highway as people attempt to flee amid lockdown. The Guardian. 20 April 2020. https://www.theguardian.com/world/2020/apr/20/peru-riotpolice-highway-teargas-coronavirus-lockdown

Collyns D. 2020b. 'We are living in a catastrophe': Peru's jungle capital choking for breath as Covid-19 hits. 7 May 2020. https://www.theguardian.com/globaldevelopment/2020/may/07/peru-jungle-iquitos-coronavirus-covid-19

Conticini E, Frediani B, Caro D. 2020. Can atmospheric pollution be considered a co-factor in extremely high level of SARS-CoV-2 lethality in Northern Italy? Environmental Pollution:114465. DOI: 10.1016/j.envpol.2020.114465

Corlett R, T. 2007. The impact of hunting on the mammalian fauna of tropical Asian forests. Biotropica 39:292-303.

Corlett RT, Primack RB, Devictor V, Maas B, Goswami VR, Bates AE, Koh LP, Regan TJ, Loyola R, Pakeman RJ, Cumming GS, Pidgeon A, Johns D, Roth R. 2020. Impacts of the coronavirus pandemic on biodiversity conservation. Biological Conservation 246:108571. DOI: 10.1016/j.biocon.2020.108571

Crippa P, Castruccio S, Archer-Nicholls S, Lebron GB, Kuwata M, Thota A, Sumin S, Butt E, Wiedinmyer C, Spracklen DV. 2016. Population exposure to hazardous air quality due to the 2015 fires in Equatorial Asia. Scientific Reports 6:37074. doi: 10.1038/srep37074

Crump J. 2017. Smoke on Water - Countering Global Threats From Peatland Loss and Degradation. A UNEP Rapid Response Assessment. Nairobi and Arendal: United Nations Environment Programme and GRID-Arendal. www.grida.no

Cui Y, Zhang Z-F, Froines J, Zhao J, Wang H, Yu S-Z, Detels R. 2003. Air pollution and case fatality of SARS in the People's Republic of China: an ecologic study. Environmental Health 2:15. DOI: 10.1186/1476-069X-2-15

Damas J, Hughes GM, Keough KC, Painter CA, Persky NS, Corbo M, Hiller M, Koepfli K-P, Pfenning AR, Zhao H, Genereux DP, Swofford R, Pollard KS, Ryder OA, Nweeia MT, Lindblad-Toh K, Teeling EC, Karlsson EK, Lewin HA. 2020. Broad host range of SARSCoV-2 predicted by comparative and structural analysis of ACE2 in vertebrates. Proceedings of the National Academy of Sciences. DOI: 10.1073/pnas.2010146117

Dargie GC, Lawson IT, Rayden TJ, Miles L, Mitchard ETA, Page SE, Bocko YE, Ifo SA, Lewis SL. 2019. Congo Basin peatlands: threats and conservation priorities. Mitigation and Adaptation Strategies for Global Change 24:669-686. DOI: 10.1007/s11027-017-9774-8

Dargie GC, Lewis SL, Lawson IT, Mitchard ETA, Page SE, Bocko YE, Ifo SA. 2017. Age, extent and carbon storage of the central Congo Basin peatland complex. Nature 542:8690. doi: 10.1038/nature21048

Davies SE, Bennet B. 2016. A gendered human rights analysis of Ebola and Zika: locating gender in global health emergencies. International Affairs 92:1041-1060. DOI: $10.1111 / 1468-2346.12704$

de Paz C, Muller M, Munoz Boudet A, Maria Gaddis I. 2020. Gender Dimensions of the COVID-19 Pandemic. World Bank Group. DOI: 10.1596/33622

Peer) reviewing PDF | (2020:06:50176:1:1:NEW 10 Sep 2020) 
1132

1133

1134

1135

1136

1137

1138

1139

1140

1141

1142

1143

1144

1145

1146

1147

1148

1149

1150

1151

1152

1153

1154

1155

1156

1157

1158

1159

1160

1161

1162

1163

1164

1165

1166

1167

1168

1169

1170

1171

1172

1173

1174

1175

1176

1177

Demetriadi A. 2020. As the virus ravages Indonesia's economy, will the new capital be shelved? Southeast Asia Globe. 17 July 2020. https://southeastasiaglobe.com/indonesias-newcapital-covid19/

Ditekemena J. 2020. COVID-19 amidst Ebola's retreat. Science 368:445-445. DOI: 10.1126/science.abc4859

Dobson AP, Pimm SL, Hannah L, Kaufman L, Ahumada JA, Ando AW, Bernstein A, Busch J, Daszak P, Engelmann J, Kinnaird MF, Li BV, Loch-Temzelides T, Lovejoy T, Nowak K, Roehrdanz PR, Vale MM. 2020. Ecology and economics for pandemic prevention. Science 369:379-381. DOI: 10.1126/science.abc3189

Dohong A, Abdul Aziz A, Dargusch P. 2018. A review of techniques for effective tropical peatland restoration. Wetlands 38:275-292. DOI: 10.1007/s13157-018-1017-6

Dommain R, Dittrich I, Giesen W, Joosten H, Rais D, Silvius M, Wibisono I. 2016. Ecosystem services, degradation and restoration of peat swamps in the Southeast Asian tropics. In: Bonn A, Allott T, Evans M, Stoneman R, Joosten H, eds. Peatland Restoration and Ecosystem Services: Science, Policy and Practice. Cambridge: Cambridge University Press, 255-290.

Dong E, Du H, Gardner L. 2020. An interactive web-based dashboard to track COVID-19 in real time. The Lancet Infectious Diseases 20:533-534. DOI: 10.1016/S1473-3099(20)30120-1

Douglas I. 2006. The local drivers of land degradation in South-East Asia. Geographical Research 44:123-134. DOI: 10.1111/j.1745-5871.2006.00373.x

Dove M. 2011. The Banana Tree at the Gate: A History of Marginal Peoples and Global Markets in Borneo. New Haven: Yale University Press.

EIA-TELAPAK. 1999. The Final Cut, Illegal Logging in Indonesia's Orangutan Parks. Environmental Investigation Agency and Telapak Indonesia.

El Peruano. 2020. Normas Legales. Decreto Supremo No. 101-2020-PCM [Legal Norms. Supreme Decree No. 101-2020-PCM]. El Peruano. 4 June 2020. pp 17-20. https://cdn.www.gob.pe/uploads/document/file/818735/DS 101-2020PCM.pdf (accessed via: https://diariooficial.elperuano.pe/normas).

El Zowalaty ME, Järhult JD. 2020. From SARS to COVID-19: A previously unknown SARSrelated coronavirus (SARS-CoV-2) of pandemic potential infecting humans - Call for a One Health approach. One Health 9:100124. DOI: 10.1016/j.onehlt.2020.100124

Ellwanger JH, Kulmann-Leal B, Kaminski VL, Valverde-Villegas JM, Veiga A, Spilki FR, Fearnside PM, Caesar L, Giatti LL, Wallau GL, Almeida SEM, Borba MR, Hora VPD, Chies JAB. 2020. Beyond diversity loss and climate change: Impacts of Amazon deforestation on infectious diseases and public health. An Acad Bras Cienc 92:e20191375. DOI: 10.1590/0001-3765202020191375

Elmhirst R, Siscawati M, Basnett BS, Ekowati D. 2017. Gender and generation in engagements with oil palm in East Kalimantan, Indonesia: insights from feminist political ecology. The Journal of Peasant Studies 44:1135-1157. DOI: 10.1080/03066150.2017.1337002

Euler M, Hoffmann MP, Fathoni Z, Schwarze S. 2016. Exploring yield gaps in smallholder oil palm production systems in eastern Sumatra, Indonesia. Agricultural Systems 146:111119. DOI: $10.1016 /$ j.agsy.2016.04.007

Evans KL, Ewen JG, Guillera-Arroita G, Johnson JA, Penteriani V, Ryan SJ, Sollmann R, Gordon IJ. 2020. Conservation in the maelstrom of Covid-19 - a call to action to solve the challenges, exploit opportunities and prepare for the next pandemic. Animal Conservation 23:235-238. DOI: 10.1111/acv.12601

Peer] reviewing PDF | (2020:06:50176:1:1:NEW 10 Sep 2020) 
1178

1179

1180

1181

1182

1183

1184

1185

1186

1187

1188

1189

1190

1191

1192

1193

1194

1195

1196

1197

1198

1199

1200

1201

1202

1203

1204

1205

1206

1207

1208

1209

1210

1211

1212

1213

1214

1215

1216

1217

1218

1219

1220

1221

1222

Evers S, Yule CM, Padfield R, O'Reilly P, Varkkey H. 2017. Keep wetlands wet: the myth of sustainable development of tropical peatlands - implications for policies and management. Global Change Biology 23:534-549. DOI: 10.1111/gcb.13422

Fa JE, Currie D, Meeuwig J. 2003. Bushmeat and food security in the Congo Basin: linkages between wildlife and people's future. Environmental Conservation 30:71-78. DOI: $10.1017 / \mathrm{S} 0376892903000067$

FAO. 2020. Forest and farm facility. Food and Agriculture Organization of the United Nations. 20 June 2020. http://www.fao.org/forest-farm-facility/coviden/en/

FAO, IFAD, UNICEF, WFP, WHO. 2019. The State of Food Security and Nutrition in the World 2019. Safeguarding against economic slowdowns and downturns Rome: Food and Agriculture Organization.

Field RD, van der Werf GR, Shen SSP. 2009. Human amplification of drought-induced biomass burning in Indonesia since 1960. Nature Geoscience 2:185-188. DOI: 10.1038/NGEO443

Frontera A, Martin C, Vlachos K, Sgubin G. 2020. Regional air pollution persistence links to COVID-19 infection zoning. The Journal of infection 81:318-356. DOI: 10.1016/j.jinf.2020.03.045

Gan M, Choo A, Leng KY, Sharif N. 2020. SIIA Haze Outlook. Singapore: Singapore Institute of International Affairs. http://www.siiaonline.org/wp-content/uploads/2020/06/SIIA-HazeOutlook-2020.pdf

Gaughan AE, Stevens FR, Linard C, Jia P, Tatem AJ. 2013. High resolution population distribution maps for Southeast Asia in 2010 and 2015. PLoS One 8:e55882. DOI: 10.1371/journal.pone.0055882

Gaveau DLA, Salim MA, Hergoualc'h K, Locatelli B, Sloan S, Wooster M, Marlier ME, Molidena E, Yaen H, DeFries R, Verchot L, Murdiyarso D, Nasi R, Holmgren P, Sheil D. 2014. Major atmospheric emissions from peat fires in Southeast Asia during non-drought years: evidence from the 2013 Sumatran fires. Scientific Reports 4:6112. DOI: 10.1038/srep06112

Gillespie TR, Ahouka S, Ancrenaz M, Bergl R, Calvignac-Spencer S, Couacy-Hymann E, Deschner T, Duex A, Fuh-Neba T, Gogarten JF, Herbinger I, Kalema-Zikusoka G, Kone I, Lonsdorf EV, Lumbu Banza C-P, Makoutoutou Nzassi P, Raphael J, Mpungu DC, Patrono LV, Refisch J, Robbins M, Rwego IB, Surbeck M, Wich S, Wittig R, Leendertz FH. 2020. COVID-19: protect great apes during human pandemics. Nature 579:497. DOI: $10.1038 / \mathrm{d} 41586-020-00859-\mathrm{y}$

Gloede O, Menkhoff L, Waibel H. 2015. Shocks, individual risk attitude, and vulnerability to poverty among rural households in Thailand and Vietnam. World Development 71:54-78. DOI: $10.1016 /$ j.worlddev.2013.11.005

Gokkon B. 2020. Indonesia's new capital in the Bornean jungle on hold amid COVID-19 crisis. Mongabay. 15 April 2020. https://news.mongabay.com/2020/04/indonesias-new-capitalin-the-bornean-jungle-on-hold-amid-covid-19-crisis/

Graham LLB, Giesen W, Page SE. 2017. A common-sense approach to tropical peat swamp forest restoration in Southeast Asia. Restoration Ecology 25:312-321. DOI: $10.1111 /$ rec. 12465

Haensler A, Saeed F, Jacob D. 2013. Assessing the robustness of projected precipitation changes over central Africa on the basis of a multitude of global and regional climate projections. Climatic Change 121:349-363. DOI: 10.1007/s10584-013-0863-8 
1223

1224

1225

1226

1227

1228

1229

1230

1231

1232

1233

1234

1235

1236

1237

1238

1239

1240

1241

1242

1243

1244

1245

1246

1247

1248

1249

1250

1251

1252

1253

1254

1255

1256

1257

1258

1259

1260

1261

1262

1263

1264

1265

1266

1267

1268
Hanafiah J. 2020. Poaching in Indonesia's biodiverse Leuser Ecosystem on the rise amid COVID-19. Mongabay. 28 May 2020. https://news.mongabay.com/2020/05/wildlifepoaching-indonesia-leuser-covid19-tiger-orangutan-rhino/

Harrison ME, Cheyne SM, Darma F, Ribowo DA, Limin SH, Struebig MJ. 2011. Hunting of flying foxes and perception of disease risk in Indonesian Borneo. Biological Conservation 144:2441-2449. DOI: 10.1016/j.biocon.2011.06.021

Harrison ME, Ottay JB, D’Arcy LJ, Cheyne SM, Anggodo, Belcher C, Cole L, Dohong A, Ermiasi Y, Feldpausch T, Gallego-Sala A, Gunawan A, Höing A, Husson SJ, Kulu IP, Soebagio SM, Mang S, Mercado L, Morrogh-Bernard HC, Page SE, Priyanto R, Ripoll Capilla B, Rowland L, Santos E, Schreer V, Sudyana IN, Bin Bakeri Taman S, Thornton SA, Upton C, Wich SA, van Veen F. 2020. Tropical forest and peatland conservation in Indonesia: Challenges and directions. People and Nature 2:4-28. DOI: 10.1002/pan3.10060

Harrison RD, Sreekar R, Brodie JF, Brook S, Luskin M, O'Kelly H, Rao M, Scheffers B, Velho N. 2016. Impacts of hunting on tropical forests in Southeast Asia. Conservation Biology 30:972-981. DOI: 10.1111/cobi.12785

Hilser H. 2011. An Assessment of Primate Health in the Sabangau Peat-Swamp Forest, Central Kalimantan, Indonesian Borneo. MSc thesis, Oxford Brookes University, UK.

Hilser H, Ehlers Smith YC, Ehlers Smith DA. 2014. Apparent mortality as a result of an elevated parasite infection in Presbytis rubicunda. Folia Primatologica 85:265-276. DOI: $10.1159 / 000363740$

Hockings M, Dudley N, Ellio W, Ferreira MN, MacKinnon K, Pasha M, Phillips A, Stolton S, Woodley S, Appleton M, Chassot O, Fitzsimons J, Galliers C, Kroner RG, Goodrich J, Hopkins J, Jackson W, Jonas H, Long B, Mumba M, Parrish J, Paxton M, Phua C, Plowright R, Rao M, Redford K, Robinson J, Rodríguez CM, Sandwith T, Spenceley A, Stevens C, Tabor G, Troëng S, Willmore S, Yang A. 2020. Editorial essay: COVID-19 and Protected and Conserved Areas. PARKS 26:7-24. DOI: 10.2305/IUCN.CH.2020.PARKS-26-1MH.en

Hooijer A, Page S, Canadell JG, Silvius M, Kwadijk J, Wösten H, Jauhiainen J. 2009. Current and future $\mathrm{CO}_{2}$ emissions from drained peatlands in Southeast Asia. Biogeosciences Discussions 6:7207-7230. DOI: 10.5194/bg-7-1505-2010

Hurowitz G. 2020. The coronavirus climate profiteers ... and the climate heroes doing the right thing in a time of crisis. Mighty Earth (accessed 2 May 2020). https://stories.mightyearth.org/the-coronavirus-climate-profiteers/index.html

Husson SJ, Limin SH, Adul, Boyd NS, Brousseau JJ, Collier S, Cheyne SM, D’Arcy LJ, Dow RA, Dowds NW, Dragiewicz ML, Smith DAE, Iwan, Harsanto FA, Hendri, Houlihan PR, Jeffers KA, Jarrett BJM, Kulu IP, Morrogh-Bernard HC, Page SE, Perlett ED, Purwanto A, Capilla BR, Salahuddin, Santiano, Schreven SJJ, Struebig MJ, Thornton SA, Tremlett C, Yeen Z, Harrison ME. 2018. Biodiversity of the Sabangau tropical peatswamp forest, Indonesian Borneo. Mires and Peat 22:1-50. DOI: 10.19189/MaP.2018.OMB.352

IMF. 2020. World Economic Outlook: April 2020. International Monetary Fund.

Index Mundi. 2020. Commodity Prices - Palm Oil. Index Mundi (accessed 20 June 2020). https://www.indexmundi.com/commodities/?commodity=palm-oil\&months

Inogwabini B-I, Abokome M, Kamenge T, Mbende L, Mboka L. 2012. Preliminary bonobo and chimpanzee nesting by habitat type in the northern Lac Tumba Landscape, Democratic 
1269

1270

1271

1272

1273

1274

1275

1276

1277

1278

1279

1280

1281

1282

1283

1284

1285

1286

1287

1288

1289

1290

1291

1292

1293

1294

1295

1296

1297

1298

1299

1300

1301

1302

1303

1304

1305

1306

1307

1308

1309

1310

1311

1312

1313

1314

Republic of Congo. African Journal of Ecology 50:285-298. DOI: 10.1111/j.13652028.2012.01323.x

Iskandar AH. 2020. Surat Edaran Menteri Desa, Pembangunan Daerah Tertinggal, dan Transmigrasi No. 8 Tahun 2020 tentang Desa Tanggap COVID-19 dan Penegasan Padat Karya Tunai Desa [Circular Letter of the Minister of Villages, Development of Disadvantaged Regions, and Transmigration No. 8/2020 on COVID-19 Ready Village and the Affirmation of Cash Village Padat Karya]. Jakarta, Indonesia: Ministry of Villages, Development of Disadvantaged Regions, and Transmigration.

IUCN. 2020. Amplifying Indigenous Voices: IUCN Indigenous Members' Solutions and Challenges Related to the COVID-19 Crisis. International Union for Conservation of Nature. https://www.iucn.org/sites/dev/files/ipo-c19-brief.pdf

IUCN SSC PSG SGA. 2020. COVID-19 and Great Apes: Advisory for Conservation Teams Operating in Great Ape Habitat During the COVID-19 Pandemic. IUCN SSC Primate Specialist Group, Section on Great Apes. http://static1.1.sqspcdn.com/static/f/1200343/28319773/1593547413467/COVID19 advisory for_conservation field teams.pdf?token=VxfNtaYPReJa73UifZyT6AoHB QQ\%3D

IUCN SSC WHSG, PSG SGA. 2020. Great Apes, COVID-19 and the SARS CoV-2 Joint Statement of the IUCN SSC Wildlife Health Specialist Group and the Primate Specialist Group, Section on Great Apes.

https://www.cms.int/sites/default/files/uploads/gorilla/pdf/Final\%20-\%20SARS $\% 20 \mathrm{CoV}$ 2\%20and\%20Great\%20Apes\%20Joint \%20Communique\%2016-05-20.pdf

Jakarta Post. 2020. Life without internet: Bornean students learn by radio during pandemic. Jakarta Post. 2 May 2020. https://www.thejakartapost.com/news/2020/05/02/lifewithout-internet-bornean-students-learn-by-radio-duringpandemic.html?src=mostviewed\&pg=news/2020/05/03/fight-against-illegal-loggingcould-be-cut-back-by-mobility-restrictions-ngo.html

Jelsma I, Schoneveld GC, Zoomers A, van Westen ACM. 2017. Unpacking Indonesia's independent oil palm smallholders: An actor-disaggregated approach to identifying environmental and social performance challenges. Land Use Policy 69:281-297. DOI: 10.1016/j.landusepol.2017.08.012

Johnson CK, Hitchens PL, Pandit PS, Rushmore J, Evans TS, Young CCW, Doyle MM. 2020. Global shifts in mammalian population trends reveal key predictors of virus spillover risk. Proceedings of the Royal Society B: Biological Sciences 287:20192736. DOI: 10.1098/rspb.2019.2736

Jones KE, Patel NG, Levy MA, Storeygard A, Balk D, Gittleman JL, Daszak P. 2008. Global trends in emerging infectious diseases. Nature 451. DOI: $10.1038 /$ nature 0653

Jong HN. 2020a. Experts see environmental, social fallout in Indonesia's infrastructure push. Mongabay. 15 June 2020. https://news.mongabay.com/2020/06/indonesia-nationalstrategic-project-infrastructure-road-railway-dam-smelter-nickel-peatland/

Jong HN. 2020b. Forest fires in Indonesia set to add toxic haze to COVID-19 woes. 23 April 2020. https://news.mongabay.com/2020/04/forest-fires-in-indonesia-look-set-to-addtoxic-haze-to-covid-19-woes/

Jong HN. 2020c. Indonesia won't 'sacrifice economy' for more ambitious emissions cuts. Mongabay. 14 April 2020. https://news.mongabay.com/2020/04/indonesia-emissionsreduction-climate-carbon-economy-growth/ 
1315

1316

1317

1318

1319

1320

1321

1322

1323

1324

1325

1326

1327

1328

1329

1330

1331

1332

1333

1334

1335

1336

1337

1338

1339

1340

1341

1342

1343

1344

1345

1346

1347

1348

1349

1350

1351

1352

1353

1354

1355

1356

1357

1358

1359

1360

Jong HN. 2020d. Indonesian lawmakers push to pass deregulation bills as COVID-19 grips country. Mongabay. 6 April 2020. https://news.mongabay.com/2020/04/indonesiaparliament-dpr-omnibus-bill-mining-covid19/

Julia, White B. 2012. Gendered experiences of dispossession: oil palm expansion in a Dayak Hibun community in West Kalimantan. The Journal of Peasant Studies 39:995-1016. DOI: 10.1080/03066150.2012.676544

Kandala N-B, Madungu TP, Emina JBO, Nzita KPD, Cappuccio FP. 2011. Malnutrition among children under the age of five in the Democratic Republic of Congo (DRC): does geographic location matter? BMC Public Health 11:261. DOI: 10.1186/1471-2458-11261

Kanniah KD, Kamarul Zaman NAF, Kaskaoutis DG, Latif MT. 2020. COVID-19's impact on the atmospheric environment in the Southeast Asia region. Science of The Total Environment 736:139658. DO: 10.1016/j.scitotenv.2020.139658

Kavousi J, Goudarzi F, Izadi M, Gardner CJ. 2020. Conservation needs to evolve to survive in the post-pandemic world. Global Change Biology 26:4651-4653. DOI: $10.1111 / \mathrm{gcb} .15197$

Keesing F, Belden LK, Daszak P, Dobson A, Harvell CD, Holt RD, Hudson P, Jolles A, Jones KE, Mitchell CE, Myers SS, Bogich T, Ostfeld RS. 2010. Impacts of biodiversity on the emergence and transmission of infectious diseases. Nature 468:647-652. DOI: 10.1038 /nature09575

Kobo Y. 2020. Why coronavirus means the EU must suspend its palm oil ban. The Parliament Magazine. 20 March 2020. https://www.theparliamentmagazine.eu/articles/partner article/why-coronavirus-meanseu-must-suspend-its-palm-oil-ban

Köndgen S, Kühl H, N'Goran PK, Walsh PD, Schenk S, Ernst N, Biek R, Formenty P, MätzRensing K, Schweiger B, Junglen S, Ellerbrok H, Nitsche A, Briese T, Lipkin WI, Pauli G, Boesch C, Leendertz FH. 2008. Pandemic human viruses cause decline of endangered great apes. Current Biology 18:260-264. DOI: 10.1016/j.cub.2008.01.012

Koon LC, Cranbrook Eo. 2014. Swiftlets of Borneo: Builders of Edible Nests. Second Edition. Kota Kinibalu: Natural History Publications (Borneo).

Koplitz SN, Mickley LJ, Marlier ME, Buonocore JJ, Kim PS, Liu T, Sulprizio MP, DeFries RS, Jacob DJ, Schwartz J, Pongsiri M, Myers SS. 2016. Public health impacts of the severe haze in Equatorial Asia in September-October 2015: demonstration of a new framework for informing fire management strategies to reduce downwind smoke exposure.

Environmental Research Letters 11:094023. DOI: 10.1088/1748-9326/11/9/094023

KPA. 2019. Catatan Akhir Tahun 2018 [Year End Notes 2018]. Jakarta, Indonesia: Konsorsium Pembaruan Agraria.

Krishnan L, Akande T, Shankar AV, McIntire KN, Gounder CR, Gupta A, Yang W-T. 2014. Gender-related barriers and delays in accessing tuberculosis diagnostic and treatment services: a systematic review of qualitative studies. Tuberculosis Research and Treatment 2014:215059-215059. DOI: 10.1155/2014/215059

Laborde D, Martin W, Swinnen J, Vos R. 2020. COVID-19 risks to global food security. Science 369:500-502. DOI: 10.1126/science.abc4765

Lansbury L, Lim B, Baskaran V, Lim WS. 2020. Co-infections in people with COVID-19: a systematic review and meta-analysis. Journal of Infection 81:266-275. DOI: 10.1016/j.jinf.2020.05.046 
1361

1362

1363

1364

1365

1366

1367

1368

1369

1370

1371

1372

1373

1374

1375

1376

1377

1378

1379

1380

1381

1382

1383

1384

1385

1386

1387

1388

1389

1390

1391

1392

1393

1394

1395

1396

1397

1398

1399

1400

1401

1402

1403

1404

Lappan S, Malaivijitnond S, Radhakrishna S, Riley EP, Ruppert N. 2020. The human-primate interface in the New Normal: Challenges and opportunities for primatologists in the COVID-19 era and beyond. American Journal of Primatology:e23176. DOI: 10.1002/ajp. 23176

Laurance WF, Goosem M, Laurance SGW. 2009. Impacts of roads and linear clearings on tropical forests. Trends in Ecology \& Evolution 24:659-669. DOI: 10.1016/j.tree.2009.06.009

Le Quéré C, Jackson RB, Jones MW, Smith AJP, Abernethy S, Andrew RM, De-Gol AJ, Willis DR, Shan Y, Canadell JG, Friedlingstein P, Creutzig F, Peters GP. 2020. Temporary reduction in daily global $\mathrm{CO} 2$ emissions during the COVID-19 forced confinement. Nature Climate Change. DOI: 10.1038/s41558-020-0797-x

Lee C, Rogers WA, Braunack-Mayer A. 2008. Social justice and pandemic influenza planning: the role of communication strategies. Public Health Ethics 1:223-234. DOI: $10.1093 / \mathrm{phe} / \mathrm{phn} 031$

Leifeld J, Menichetti L. 2018. The underappreciated potential of peatlands in global climate change mitigation strategies. Nature Communications 9:1071. DOI: 10.1038/s41467-01803406-6

Li T. 2014. Land's End: Capitalist Relations on an Indigenous Frontier. Durham and London: Duke University Press.

Li X, Giorgi EE, Marichannegowda MH, Foley B, Xiao C, Kong X-P, Chen Y, Gnanakaran S, Korber B, Gao F. 2020. Emergence of SARS-CoV-2 through recombination and strong purifying selection. Science Advances eabb9153. DOI: 10.1126/sciadv.abb9153

Lilleskov E, McCullough K, Hergoualc'h K, del Castillo Torres D, Chimner R, Murdiyarso D, Kolka R, Bourgeau-Chavez L, Hribljan J, del Aguila Pasquel J, Wayson C. 2019. Is Indonesian peatland loss a cautionary tale for Peru? A two-country comparison of the magnitude and causes of tropical peatland degradation. Mitigation and Adaptation Strategies for Global Change 24:591-623. DOI: 10.1007/s11027-018-9790-3

Linard C, Gilbert M, Snow RW, Noor AM, Tatem AJ. 2012. Population distribution, settlement patterns and accessibility across Africa in 2010. PLoS One 7:e31743. DOI: 10.1371/journal.pone.0031743

Lindsey P, Allan J, Brehony P, Dickman A, Robson A, Begg C, Bhammar H, Blanken L, Breuer T, Fitzgerald K, Flyman M, Gandiwa P, Giva N, Kaelo D, Nampindo S, Nyambe N, Steiner K, Parker A, Roe D, Thomson P, Trimble M, Caron A, Tyrrell P. 2020. Conserving Africa's wildlife and wildlands through the COVID-19 crisis and beyond. Nature Ecology \& Evolution. DOI: 10.1038/s41559-020-1275-6

Listiyorini E. 2020. Indonesia says looming haze can worsen health of virus patients. Bloomberg. 8 May 2020. https://www.bloomberg.com/news/articles/2020-05-08/indonesia-sayslooming-haze-can-worsen-health-of-virus-patients

Listori E. 2020. Indonesia plans village squads to prevent spread of Coronavirus. Bloomberg. 31 March 2020. https://www.bloomberg.com/news/articles/2020-03-31/indonesia-plansvillage-squads-to-prevent-spread-of-coronavirus

Lucas B. 2020. Impacts of Covid-19 on Inclusive Economic Growth in Middle-Income Countries. K4D Helpdesk Report 811. Brighton, UK: Institute of Development Studies. https://opendocs.ids.ac.uk/opendocs/handle/20.500.12413/15310

Peer) reviewing PDF | (2020:06:50176:1:1:NEW 10 Sep 2020) 
1405

1406

1407

1408

1409

1410

1411

1412

1413

1414

1415

1416

1417

1418

1419

1420

1421

1422

1423

1424

1425

1426

1427

1428

1429

1430

1431

1432

1433

1434

1435

1436

1437

1438

1439

1440

1441

1442

1443

1444

1445

1446

1447

1448

Lupton D. 2020. Doing fieldwork in a pandemic (crowd-sourced document). Available at: https://docs.google.com/document/d/1clGjGABB2h2qbduTgfqribHmog9B6P0NvMgVui HZCl8/edit?ts=5e88ae0a\#

MacFarlane D, Rocha R. 2020. Guidelines for communicating about bats to prevent persecution in the time of COVID-19. Biological Conservation 248:108650. DOI: 10.1016/j.biocon.2020.108650

Madinah A, Abang F, Mariana A, Abdullah MT, Mohd-Azlan J. 2014. Interaction of ectoparasites-small mammals in tropical rainforest of Malaysia. Community Ecology 15:113. DOI: $10.1556 /$ comec.15.2014.1.12

Madinah A, Fatimah A, Mariana A, Abdullah MT. 2011. Ectoparasites of small mammals in four localities of wildlife reserves in Peninsular Malaysia. Southeast Asian Journal of Tropical Medicine and Public Health 42:803-813

Mäki S, Kalliola R, Vuorinen K. 2001. Road construction in the Peruvian Amazon: process, causes and consequences. Environmental Conservation 28:199-214. DOI: $10.1017 / \mathrm{S} 0376892901000212$

Mayor P, El Bizri HR, Morcatty TQ, Moya K, Solis S, Bodmer RE. 2019. Assessing the minimum sampling effort required to reliably monitor wild meat trade in urban markets. Frontiers in Ecology and Evolution 7:180. DOI: 10.3389/fevo.2019.00180

McCarthy J, Robinson K. 2016. Land and Development in Indonesia: Searching for the People's Sovereignty. Singapore: ISEAS-Yusof Ishak Institute.

Medrilzam M, Dargusch P, Herbohn J, Smith C. 2014. The socio-ecological drivers of forest degradation in part of the tropical peatlands of Central Kalimantan, Indonesia. Forestry: An International Journal of Forest Research 87:335-345. DOI: 10.1093/forestry/cpt033

Melin AD, Janiak MC, Marrone F, Arora PS, Higham JP. 2020. Comparative ACE2 variation and primate COVID-19 risk. bioRxiv:2020.2004.2009.034967. DOI: 10.1101/2020.04.09.034967

Miettinen J, Shi C, Liew SC. 2016. Land cover distribution in the peatlands of Peninsular Malaysia, Sumatra and Borneo in 2015 with changes since 1990. Global Ecology and Conservation 6:67-78. DOI: 10.1016/j.gecco.2016.02.004

Miles L, Ravilious C, García-Rangel S, de Lamo X, Dargie G, Lewis S. 2017. Carbon, Biodiversity and Land-use in the Central Congo Basin Peatlands. United Nations Environment Programme.

Milko V. 2020. Pandemic poses special threat to indigenous health, culture. AP News. 7 May 2020. https://apnews.com/fb15142c3d209c92ef2f502a4ba0d6fa

Mistry J, Berardi A. 2016. Bridging indigenous and scientific knowledge. Science 352:12741275. DOI: $10.1126 /$ science.aaf 1160

Mizuno K, Fujita MS, Kawai S. 2016. Catastrophe \& Regeneration in Indonesia's Peatlands: Ecology, Economy \& Society. Singapore: NUS Press.

MoH RoI. 2019. Indonesia Health Profile 2018. Jakarta, Indonesia: Ministry of Health of the Republic of Indonesia. https://www.kemkes.go.id/resources/download/pusdatin/profilkesehatan-indonesia/indonesia-health-profile-2018.pdf

Moore P, Hannah B, de Vries J, Poortvliet M, Steffens R, Stoof CR. 2020. Wildland Fire Management Under COVID-19. Brief 1, Review of Materials. Wageningen: Wageningen University. DOI: $10.18174 / 521344$

Peer) reviewing PDF | (2020:06:50176:1:1:NEW 10 Sep 2020) 
1449

1450

1451

1452

1453

1454

1455

1456

1457

1458

1459

1460

1461

1462

1463

1464

1465

1466

1467

1468

1469

1470

1471

1472

1473

1474

1475

1476

1477

1478

1479

1480

1481

1482

1483

1484

1485

1486

1487

1488

1489

1490

1491

1492

Muyembe-Tamfum JJ, Mulangu S, Masumu J, Kayembe JM, Kemp A, Paweska JT. 2012. Ebola virus outbreaks in Africa: Past and present. Onderstepoort Journal of Veterinary Research 79:06-13.

Nair N, Wares F, Sahu S. 2010. Tuberculosis in the WHO South-East Asia region. Bulletin of the World Health Organisation 88:164-165. doi: 10.2471/BLT.09.073874

Nesadurai HES. 2013. Food security, the palm oil-land conflict nexus, and sustainability: a governance role for a private multi-stakeholder regime like the RSPO? The Pacific Review 26:505-529. DOI: 10.1080/09512748.2013.842311

Nielsen MR, Meilby H, Smith-Hall C, Pouliot M, Treue T. 2018. The importance of wild meat in the global south. Ecological Economics 146:696-705. DOI: 10.1016/j.ecolecon.2017.12.018

Nijman V. 2010. An overview of international wildlife trade from Southeast Asia. Biodiversity and Conservation 19:1101-1114. DOI: 10.1007/s10531-009-9758-4

Nijman V, Spaan D, Rode-Margono EJ, Wirdateti, Nekaris KAI. 2015. Changes in the primate trade in Indonesian wildlife markets over a 25-year period: Fewer apes and langurs, more Macaques, and slow Lorises. American Journal of Primatology 79:e22517. DOI: 10.1002/ajp. 22517

Nordling L. 2020. Africa's pandemic puzzle: why so few cases and deaths? Science 369:756-757. DOI: $10.1126 /$ science.369.6505.756

Nurcahyo W, Konstanzová V, Foitová I. 2017. Parasites of orangutans (primates: ponginae): An overview. American Journal of Primatology 79:e22650. DOI: 10.1002/ajp.22650

OECD. 2020. DAC List of ODA Recipients Effective for Reporting on 2020 Flows. Organisation for Economic Co-operation and Development. http://www.oecd.org/dac/financingsustainable-development/development-finance-standards/DAC-List-of-ODA-Recipientsfor-reporting-2020-flows.pdf

Ogen Y. 2020. Assessing nitrogen dioxide $\left(\mathrm{NO}_{2}\right)$ levels as a contributing factor to coronavirus (COVID-19) fatality. Science of The Total Environment 726:138605. DOI: 10.1016/j.scitotenv.2020.138605

OGJ Editors. 2020. EIA lowers 2020 oil demand forecast amid high uncertainties. Oil \& Gas Journal. 12 May 2020. https://www.ogj.com/general-interest/economicsmarkets/article/14175840/eia-lowers-2020-oil-demand-forecast-amid-high-uncertainties

Oppenheim B, Gallivan M, Madhav NK, Brown N, Serhiyenko V, Wolfe ND, Ayscue P. 2019. Assessing global preparedness for the next pandemic: development and application of an Epidemic Preparedness Index. BMJ Global Health 4:e001157. DOI: 10.1136/bmjgh2018-001157

Page SE, Hooijer A. 2016. In the line of fire: the peatlands of Southeast Asia. Philosophical Transactions of the Royal Society of London B 371:20150176. DOI: 10.1098/rstb.2015.0176

Page SE, Rieley JO, Banks CJ. 2011. Global and regional importance of the tropical peatland carbon pool. Global Change Biology 17:798-818. DOI: 10.1111/j.13652486.2010.02279.x

PAHO. 2020. Dengue Prevention and Control During COVID-19 Pandemic. Washington, DC: Pan American Health Organization. https://www.paho.org/en/documents/dengueprevention-and-control-during-covid-19-pandemic 
1493

1494

1495

1496

1497

1498

1499

1500

1501

1502

1503

1504

1505

1506

1507

1508

1509

1510

1511

1512

1513

1514

1515

1516

1517

1518

1519

1520

1521

1522

1523

1524

1525

1526

1527

1528

1529

1530

1531

1532

1533

1534

1535

1536

1537

Parish F, Sirin A, Charman D, Joosten H, Minayeva T, Silvius M, Stringer L. 2008. Assessment on Peatlands, Biodiversity and Climate Change: Main Report. Global Environment Centre, Kuala Lumpur and Wetlands International, Wageningen.

Payne J, Bradley B. 2020. The Consequences of Pandemic-driven Inequality. Oxford: Oxford Economics.

Pearson RM, Sievers M, McClure EC, Turschwell MP, Connolly RM. 2020. COVID-19 recovery can benefit biodiversity. Science 368:838-839. DOI: 10.1126/science.abc1430

Phillips CA, Caldas A, Cleetus R, Dahl KA, Declet-Barreto J, Licker R, Merner LD, OrtizPartida JP, Phelan AL, Spanger-Siegfried E, Talati S, Trisos CH, Carlson CJ. 2020. Compound climate risks in the COVID-19 pandemic. Nature Climate Change 10:586588. DOI: $10.1038 / \mathrm{s} 41558-020-0804-2$

Pitkin K, Bedoya R. 1997. Women's multiple roles in economic crisis: Constraints and adaptation. Latin American Perspectives 24:34-49. DOI: 10.1177/0094582x9702400403

Pollock J, Lin Aung S. 2010. Critical times: gendered implications of the economic crisis for migrant workers from Burma/Myanmar in Thailand. Gender \& Development 18:213-227. DOI: $10.1080 / 13552074.2010 .491324$

Pongsiri MJ, Roman J, Ezenwa VO, Goldberg TL, Koren HS, Newbold SC, Ostfeld RS, Pattanayak SK, Salkeld DJ. 2009. Biodiversity loss affects global disease ecology. BioScience 59:945-954. DOI: 10.1525/bio.2009.59.11.6

Posa MRC, Wijedasa LS, Corlett RT. 2011. Biodiversity and conservation of tropical peat swamp forests. BioScience 61:49-57. DOI: 10.1525/bio.2011.61.1.10

Poulsen JR, Clark CJ, Mavah G, Elkan PW. 2009. Bushmeat supply and consumption in a tropical logging concession in northern Congo. Conservation Biology 23:1597-1608. DOI: $10.1111 / \mathrm{j} .1523-1739.2009 .01251 . \mathrm{x}$

Radhi NSM. 2020. Malaysians scramble ahead of RMO. Straits New Times. 18 March 2020. https://www.nst.com.my/news/nation/2020/03/575684/malaysians-scramble-balikkampung-ahead-rmo

Rédaction. 2020. Deux ong attaquent la CIB pour le décès de 57 enfants autochtones dams la Likouala [Two NGOs attack the CIB for the deaths of 57 indigenous children in Likouala]. Vox Médiaire. 18 September 2017. https://www.vox.cg/2017/09/deux-ongattaquent-cib-deces-de-57-enfants-autochtones-likouala/

Reid MJC. 2020. Is 2020 the year when primatologists should cancel fieldwork? American Journal of Primatology 82:e23161. DOI: 10.1002/ajp.23161

RISTEK-BRIN. 2020. Official Notice. Ministry of Reserach and Technology / National Agency for Research and Innovation (accessed 21 June 2020). https://frp.ristekbrin.go.id/

Robinson EJZ. 2016. Resource-Dependent Livelihoods and the Natural Resource Base. Annual Review of Resource Economics 8:281-301. DOI: 10.1146/annurev-resource-100815095521

Rodriguez JM, Molnar JJ, Fazio RA, Sydnor E, Lowe MJ. 2009. Barriers to adoption of sustainable agriculture practices: Change agent perspectives. Renewable Agriculture and Food Systems 24:60-71. DOI: 10.1017/S1742170508002421

Rodríguez Mega E. 2016. Oil spills stain Peruvian Amazon. Scientific American. 4 March 2016. https://www.scientificamerican.com/article/oil-spills-stain-peruvian-amazon/

Roger F, Caron A, Morand S, Pedrono M, Garine-Wichatitsky Md, Chevalier V, Tran A, Gaidet N, Figuié M, de Visscher M-N, Binot A. 2016. One Health and EcoHealth: the same wine 
1538

1539

1540

1541

1542

1543

1544

1545

1546

1547

1548

1549

1550

1551

1552

1553

1554

1555

1556

1557

1558

1559

1560

1561

1562

1563

1564

1565

1566

1567

1568

1569

1570

1571

1572

1573

1574

1575

1576

1577

1578

1579

1580

1581

1582

1583

in different bottles? Infection Ecology \& Epidemiology 6:30978. DOI:

10.3402/iee.v6.30978

Roucoux KH, Lawson IT, Baker TR, Del Castillo Torres D, Draper FC, Lähteenoja O, Gilmore MP, Honorio Coronado EN, Kelly TJ, Mitchard ETA, Vriesendorp CF. 2017. Threats to intact tropical peatlands and opportunities for their conservation. Conservation Biology 31:1283-1292. DOI: $10.1111 /$ cobi.12925

Sánchez-Páramo C. 2020. COVID-19 will hit the poor hardest. Here's what we can do about it. World Bank Blogs. 23 April 2020. https://blogs.worldbank.org/voices/covid-19-will-hitpoor-hardest-heres-what-we-can-do-about-it

Santika T, Meijaard E, Budihartab S, Law EA, Kusworo A, Hutabarat JA, Indrawan TP, Struebig M, Raharjo S, Huda I, Sulhani, Ekaputri AD, Trison S, Stigner M, Wilson KA. 2017. Community forest management in Indonesia: Avoided deforestation in the context of anthropogenic and climate complexities. Global Environmental Change 46:60-71. DOI: 10.1016/j.gloenvcha.2017.08.002

Sardar S, Sharma R, Alyamani TYM, Aboukamar M. 2020. COVID-19 and Plasmodium vivax malaria co-infection. IDCases 21:e00879. DOI: 10.1016/j.idcr.2020.e00879

Sarkar S. 2020. Coronavirus thumps palm oil demand. China Dialogue. 8 April 2020. https://www.chinadialogue.net/article/show/single/en/11945-Coronavirus-thumps-palmoil-demand

Schoppe S. 2009. Status, trade, dynamics and management of the Southeast Asian box turtle Cuora amboinensis in Indonesia. Petaling Jaya, Selangor, Malaysia: TRAFFIC Southeast Asia.

Schreer V. 2016. Longing for Prosperity in Indonesian Borneo. PhD dissertation. University of Kent.

Schulz C, Martín Brañas M, Núñez Pérez C, Del Aguila Villacorta M, Laurie N, Lawson IT, Roucoux KH. 2019a. Peatland and wetland ecosystems in Peruvian Amazonia: indigenous classifications and perspectives. Ecology and Society 24:12. DOI: 10.5751/ES-10886-240212

Schulz C, Martín Brañas M, Núñez Pérez C, Del Aguila Villacorta M, Laurie N, Lawson IT, Roucoux KH. 2019b. Uses, cultural significance, and management of peatlands in the Peruvian Amazon: Implications for conservation. Biological Conservation 235:189-198. DOI: 10.1016/j.biocon.2019.04.005

Scullion JJ, Vogt KA, Sienkiewicz A, Gmur SJ, Trujillo C. 2014. Assessing the influence of land-cover change and conflicting land-use authorizations on ecosystem conversion on the forest frontier of Madre de Dios, Peru. Biological Conservation 171:247-258. DOI: 10.1016/j.biocon.2014.01.036

Setti L, Passarini F, De Gennaro G, Barbieri P, Perrone MG, Borelli M, Palmisani J, Di Gilio A, Torboli V, Fontana F, Clemente L, Pallavicini A, Ruscio M, Piscitelli P, Miani A. 2020. SARS-Cov-2RNA found on particulate matter of Bergamo in Northern Italy: First evidence. Environmental Research 188:109754. DOI: 10.1016/j.envres.2020.109754

Sharp PM, Hahn BH. 2011. Origins of HIV and the AIDS pandemic. Cold Spring Harbor perspectives in medicine 1:a006841-a006841. DOI: 10.1101/cshperspect.a006841

Sierra Praeli Y. 2020. Indigenous people are most vulnerable to the spread of coronavirus in Latin America. Mongabay. 30 March 2020. https://news.mongabay.com/2020/03/indigenous-people-are-most-vulnerable-to-thespread-of-coronavirus-in-latin-america/ 
1584

1585

1586

1587

1588

1589

1590

1591

1592

1593

1594

1595

1596

1597

1598

1599

1600

1601

1602

1603

1604

1605

1606

1607

1608

1609

1610

1611

1612

1613

1614

1615

1616

1617

1618

1619

1620

1621

1622

1623

1624

1625

1626

1627

1628

Staniscuaski F, Reichert F, Werneck FP, de Oliveira L, Mello-Carpes PB, Soletti RC, Almeida CI, Zandona E, Ricachenevsky FK, Neumann A, Schwartz IVD, Tamajusuku ASK, Seixas A, Kmetzsch L. 2020. Impact of COVID-19 on academic mothers. Science 368:724-724. DOI: $10.1126 /$ science.abc2740

Steinberg P. 2020. Free COVID-19 illustrations, SARS-CoV-2 virus and world. Accessed 21 April 2020. Innovative Genomics Institute. https://innovativegenomics.org/free-covid-19illustrations/

Stockwell CE, Jayarathne T, Cochrane MA, Ryan KC, Putra EI, Saharjo BH, Nurhayati AD, Albar I, Blake DR, Simpson IJ, Stone EA, Yokelson RJ. 2016. Field measurements of trace gases and aerosols emitted by peat fires in Central Kalimantan, Indonesia, during the 2015 El Niño Atmospheric Chemistry and Physics 16:11711-11732. DOI: 10.5194/acp-16-11711-2016

Sumarga E, Hein L, Hooijer A, Vernimmen R. 2016. Hydrological and economic effects of oil palm cultivation in Indonesian peatlands. Ecology and Society 21:52. DOI: 10.5751/ES08490-210252

Sumner A, Hoy C, Ortiz-Juarez E. 2020. Estimates of the impact of COVID-19 on global poverty. WIDER Working Paper 2020/43. United Nations University World Instutute for Development Economics Research.

Suparmi, Kusumawardani N, Nambiar D, Trihono, Hosseinpoor AR. 2018. Subnational regional inequality in the public health development index in Indonesia. Global Health Action 11:41-53. DOI: $10.1080 / 16549716.2018 .1500133$

Suyanto S. 2007. Underlying cause of fire: Different form of land tenure conflicts in Sumatra. Mitigation and Adaptation Strategies to Global Change 12:67-74. DOI: 10.1007/s11027006-9039-4

Tan-Soo J-S, Pattanayak SK. 2019. Seeking natural capital projects: Forest fires, haze, and earlylife exposure in Indonesia. Proceedings of the National Academy of Sciences 116:52395245. DOI: $10.1073 /$ pnas. 1802876116

Taylor DE. 2015. Gender and racial diversity in environmental organizations: uneven accomplishments and cause for concern. Environmental Justice 8:165-180. DOI: 10.1089/env.2015.0018

Taylor M. 2020. Will coronavirus fan the flames of Southeast Asia's haze problem? Reuters. 22 April 2020. https://www.reuters.com/article/us-health-coronavirus-southeast-asia-hazidUSKCN224021

Thorburn C. 2014. The edible birds' nest boom in Indonesia and South-east Asia. Food, Culture \& Society 17:535-553. DOI: 10.2752/175174414X14006746101439

Thornton SA. 2017. (Un)tangling the Net, Tackling the Scales and Learning to Fish: An Interdisciplinary Study in Indonesian Borneo.PhD dissertation. University of Leicester.

Thornton SA, Cook S, Astiani D, Hapsari KA, Varkkey H, Cole LES, Dargie GC, Sjogersten S, Zawawi NZ, Page SE. 2019. 'Pushing the limits': experiences of women in tropical peatland research. Marine and Freshwater Research. DOI: 10.1071/MF19132

Trivedy C. 2020. Is 2020 the year when primatologists should cancel fieldwork? A reply. American Journal of Primatology 82:e23173. DOI: 10.1002/ajp.23173

Turetsky MR, Benscoter B, Page S, Rein G, van der Werf GR, Watts A. 2015. Global vulnerability of peatlands to fire and carbon loss. Nature Geoscience 8:11-14. DOI: 10.1038 /ngeo2325

Peer) reviewing PDF | (2020:06:50176:1:1:NEW 10 Sep 2020) 
1629

1630

1631

1632

1633

1634

1635

1636

1637

1638

1639

1640

1641

1642

1643

1644

1645

1646

1647

1648

1649

1650

1651

1652

1653

1654

1655

1656

1657

1658

1659

1660

1661

1662

1663

1664

1665

1666

1667

1668

1669

1670

1671

1672

1673

1674
Tyson A, Varkkey H, Choiruzzad SAB. 2018. Deconstructing the palm oil industry narrative in Indonesia: Evidence from Riau Province. Contemporary Southeast Asia 40:422-448. https://www.jstor.org/stable/26545302

Uda SK, Hein L, Atmoko D. 2019. Assessing the health impacts of peatland fires: a case study for Central Kalimantan, Indonesia. Environmental Science and Pollution Research. DOI: 10.1007/s11356-019-06264-x

UN. 2009. State of the World's Indigenous Peoples. New York: UN Department of Economic and Social Affairs. https://www.un.org/esa/socdev/unpfii/documents/SOWIP/en/SOWIP web.pdf

UN. 2020. Policy Brief: The Impact of COVID-19 on Women. United Nations. https://www.un.org/sites/un2.un.org/files/policy_brief_on_covid_impact_on_women_9 a pril 2020.pdf

UN/DESA. 2020. The Impact of COVID-19 on Indigenous Peoples. Policy Brief No. 70. Unitied Nations Department of Economic and Social Affairs. https://www.un.org/development/desa/dpad/wpcontent/uploads/sites/45/publication/PB 70.pdf

UN/EMRIP. 2020. COVID-19 Yet Another Challenge for Indigenous Peoples. UN Expert Mechanism on the Rights of Indigenous Peoples. https://www.un.org/development/desa/indigenouspeoples/wpcontent/uploads/sites/19/2020/04/EMPRIP-English.pdf

UNEP, ILRI. 2020. Preventing the Next Pandemic: Zoonotic Diseases and how to Break the Chain of Transmission. Nairobi, Kenya: United Nations Environment Programme and International Livestock Research Institute. https://wedocs.unep.org/bitstream/handle/20.500.11822/32316/ZP.pdf?sequence=1\&isAll owed $=y$

Utami-Atmoko S, Traylor-Holzer K, Rifqi MA, Siregar PG, Achmad B, Priadjati A, Husson S, Wich S, Hadisiswoyo P, Saputra F, Campbell-Smith G, Kuncoro P, Russon A, Voigt M, Santika T, Nowak M, Singleton I, Sapari I, Meididit A, Chandradewi DS, Ripoll Capilla B, Ermayanti, Lees CM. 2017. Orangutan Population and Habitat Viability Assessment: Final Report. Apple Valley, MN: IUCN/SSC Conservation Breeding Specialist Group.

van Beukering PJH, Schaafsma M, Davies O, Oskolokaite I. 2008. The Economic Value of Peatland Resources within the Central Kalimantan Peatland Project in Indonesia: Perceptions of Local Communities. Amsterdam, Netherlands: Institute for Environmental Studies.

van Vliet N, Moreno J, Gomez J, Zhou W, Fa JE, Golden C, Romeu R, Alves N, Nasi R. 2017. Bushmeat and human health: Assessing the Evidence in tropical and sub-tropical forests. Ethnobiology and Conservation 6:1-45. DOI: 10.15451/ec2017-04-6.3-1-45

Varkkey H. 2020. Air pollution and COVID-19 mortality: Considerations for Southeast Asia. AsiaGlobal Online. 23 April 2020. https://www.asiaglobalonline.hku.hk/air-pollutionand-covid-19-mortality-considerations-southeast-asia?

Varkkey H, Copeland A. 2020. Exhanging health for economic growth?: Haze in the context of public health and political economy in Malaysia. Journal of Social Health 3.

Vine Trust. 2020. An update from Vine Trust. Vine Trust. 9 April 2020. https://www.vinetrust.org/media/latest-news/an-update-from-vine-trust

Vittor AY, Gilman RH, Tielsch J, Glass G, Shields T, Lozano WS, Pinedo-Cancino V, Patz JA. 2006. The effect of deforestation on the human-biting rate of Anopheles darlingi, the 
primary vector of falciparum malaria in the Peruvian Amazon. The American Journal of Tropical Medicine and Hygiene 74:3-11. DOI: 10.4269/ajtmh.2006.74.3

Wallace S. 2020. First coronavirus deaths reported in indegenous communities in the Amazon. National Geogarphic. 14 April 2020. https://www.nationalgeographic.co.uk/science-andtechnology/2020/04/first-coronavirus-deaths-reported-indigenous-communities-amazon

WB. 2020a. Congo, Democratic Republic of - COVID-19 Strategic Preparedness and Response Project Washington, D.C.: World Bank Group. http://documents.worldbank.org/curated/en/349641585951020231/Congo-DemocraticRepublic-of-COVID-19-Strategic-Preparedness-and-Response-Project

WB. 2020b. East Asia and Pacific in the Time of COVID-19. East Asia and Pacific Economic Update (April). Washington, DC.: World Bank. DOI: 10.1596/978-1-4648-1565-2.

Wenham C, Smith J, Morgan R. 2020. COVID-19: the gendered impacts of the outbreak. The Lancet 395:846-848. DOI: 10.1016/S0140-6736(20)30526-2

Weston. 2020. Plan to drain Congo peat bog for oil could release vast amount of carbon. The Guardian. 28 February 2020. https://www.theguardian.com/environment/2020/feb/28/ridiculous-plan-to-drain-congopeat-bog-could-release-vast-amount-of-carbon-aoe

WFP. 2020. Coronavirus and the 5 major threats it poses to global food security. World Food Programme Insight. 30 March 2020. https://insight.wfp.org/covid-19-and-the-5-majorthreats-it-poses-to-global-food-security-1c4da2ff6657

WHO. 2009. Pandemic Influenza Preparedness and Response. WHO Guidance Document. Geneva, Switzerland: World Health Organization. https://www.who.int/influenza/resources/documents/pandemic guidance 04 2009/en/

WHO. 2017. State of Health Inequality: Indonesia, Geneva. Geneva: World Health Organisation. https://apps.who.int/iris/bitstream/handle/10665/259685/9789241513340eng.pdf?sequence $=1$

WHO. 2020a. At least 80 million children under one at risk of diseases such as diphtheria, measles and polio as COVID-19 disrupts routine vaccination efforts, warn Gavi, WHO and UNICEF. World Health Organization. 22 May 2020. https://www.who.int/newsroom/detail/22-05-2020-at-least-80-million-children-under-one-at-risk-of-diseases-suchas-diphtheria-measles-and-polio-as-covid-19-disrupts-routine-vaccination-efforts-warngavi-who-and-unicef

WHO. 2020b. Coronavirus Disease Situation Report - 15: Indonesia 8 July 2020. Indonesia: World Health Organisation. https://www.who.int/docs/defaultsource/searo/indonesia/covid19/external-situation-report-1508july2020.pdf?sfvrsn=42d8ee3d 2

WHO. 2020c. Ebola virus disease - Democratic Republic of the Congo. World Health Organization. 3 June 2020. https://www.who.int/csr/don/03-June-2020-ebola-drc/en/

WHO. 2020d. WHO urges countries to ensure the continuity of malaria services in the context of the COVID-19 pandemic. World Health Organization. 25 March 2020. https://www.who.int/news-room/detail/25-03-2020-who-urges-countries-to-ensure-thecontinuity-of-malaria-services-in-the-context-of-the-covid-19-pandemic

WHO, UNICEF. 2020. Water, Sanitation, Hygiene, and Waste Management for the COVID-19 Virus: Interim Guidance: 23 April 2020. World Health Organization and the United Nations Children's Fund. https://apps.who.int/iris/bitstream/handle/10665/331846/WHO2019-nCoV-IPC WASH-2020.3-eng.pdf?ua=1 
1721

1722

1723

1724

1725

1726

1727

1728

1729

1730

1731

1732

1733

1734

1735

1736

1737

1738

1739

1740

1741

1742

1743

1744

1745

1746

1747

1748

1749

1750

1751

1752

1753

1754

1755

1756

1757

1758

1759

1760

1761

1762

1763

1764

1765

Wich S, Riswan, Jenson J, Refisch J, Nellemann C. 2011. Orangutans and the economics of sustainable forest management in Sumatra. Norway:

UNEP/GRASP/PanEco/YEL/ICRAF/GRID-Arendal.

Wich SA, Garcia-Ulloa J, Kühl HS, Humle T, Lee JSH, Koh LP. 2014. Will oil palm's homecoming spell doom for Africa's great apes? Current Biology 24:1659-1663. DOI: 10.1016/j.cub.2014.05.077

Widodo J. 2020. Inpres no. 4/2020: Refocussing Kegiatan, Realokasi Anggaran, Serta Pengadaan Barang dan Jasa Dalam Rangka Percepatan Penanganan Corona Virus Disease 2019 (COVID-19) [Presidential Instruction no. 4/2020: Activity Refocussing, Budget Reallocation, and Procurement of Goods and Services in Order to Accelerate Handling of Corona Virus Disease 2019 (COVID-19)]. Jakarta, Indonesia: President of the Republic of Indonesia.

Wijedasa LS, Jauhiainen J, Könönen M, Lampela M, Vasander H, Leblanc MC, Evers S, Smith TEL, Yule CM, Varkkey H, Lupascu M, Parish F, Singleton I, Clements GR, Aziz SA, Harrison ME, Cheyne S, Anshari GZ, Meijaard E, Goldstein JE, Waldron S, Hergoualc'h K, Dommain R, Frolking S, Evans CD, Posa MRC, Glaser PH, Suryadiputra N, Lubis R, Santika T, Padfield R, Kurnianto S, Hadisiswoyo P, Lim TW, Page SE, Gauci V, Van Der Meer PJ, Buckland H, Garnier F, Samuel MK, Choo LNLK, O'Reilly P, Warren M, Suksuwan S, Sumarga E, Jain A, Laurance WF, Couwenberg J, Joosten H, Vernimmen R, Hooijer A, Malins C, Cochrane MA, Perumal B, Siegert F, Peh KSH, Comeau LP, Verchot L, Harvey CF, Cobb A, Jaafar Z, Wösten H, Manuri S, Müller M, Giesen W, Phelps J, Yong DL, Silvius M, Wedeux BMM, Hoyt A, Osaki M, Hirano T, Takahashi H, Kohyama TS, Haraguchi A, Nugroho NP, Coomes DA, Quoi LP, Dohong A, Gunawan H, Gaveau DLA, Langner A, Lim FKS, Edwards DP, Giam X, van der Werf G, Carmenta R, Verwer CC, Gibson L, Gandois L, Graham LLB, Regalino J, Wich SA, Rieley J, Kettridge N, Brown C, Pirard R, Moore S, Capilla BR, Ballhorn U, Ho HC, Hoscilo A, Lohberger S, Evans TA, Yulianti N, Blackham G, Onrizal, Husson S, Murdiyarso D, Pangala S, Cole LES, Tacconi L, Segah H, Tonoto P, Lee JSH, Schmilewski G, Wulffraat S, Putra EI, Cattau ME, Clymo RS, Morrison R, Mujahid A, Miettinen J, Liew SC, Valpola S, Wilson D, D'Arcy L, Gerding M, Sundari S, Thornton SA, Kalisz B, Chapman SJ, Su ASM, Basuki I, Itoh M, Traeholt C, Sloan S, Sayok AK, Andersen R. 2017. Denial of long-term issues with agriculture on tropical peatlands will have devastating consequences. Global Change Biology 23:977-982. DOI: 10.1111/gcb.13516.

Wijedasa LS, Sloan S, Page SE, Clements GR, Lupascu M, Evans TA. 2018. Carbon emissions from Southeast Asian peatlands will increase despite emission-reduction schemes. Global Change Biology. DOI: $10.1111 /$ gcb.14340

Wildayana E, Armanto ME. 2018. Formulating popular policies for peat restoration based on livelihoods of Llocal farmers. Journal of Sustainable Development 11:85-95. DOI: $10.5539 /$ jsd.v11n3p85

Wiseman V, Thabrany H, Asante A, Haemmerli M, Kosen S, Gilson L, Mills A, Hayen A, Tangcharoensathien V, Patcharanarumol W. 2018. An evaluation of health systems equity in Indonesia: study protocol. International Journal for Equity in Health 17:138. DOI: $10.1186 / \mathrm{s} 12939-018-0822-0$

WorldPop. 2020. Open Spatial Demographic Data and Research. (accessed 13 June 2020. www.worldpop.org 
1766

1767

1768

1769

1770

1771

1772

1773

1774

1775

1776

1777

1778

1779

1780

1781
Worobey M, Gemmel M, Teuwen DE, Haselkorn T, Kunstman K, Bunce M, Muyembe J-J, Kabongo J-MM, Kalengayi RM, Van Marck E, Gilbert MTP, Wolinsky SM. 2008. Direct evidence of extensive diversity of HIV-1 in Kinshasa by 1960. Nature 455:661-664. DOI: 10.1038 /nature 07390

Wu X, Nethery RC, Sabath BM, Braun D, Dominici F. 2020. Exposure to air pollution and COVID-19 mortality in the United States. medRxiv 2020.04.05.20054502. DOI: 10.1101/2020.04.05.20054502

Yusoff NM, Muharam FM, Khairunniza-Bejo S. 2017. Towards the use of remote-sensing data for monitoring of abandoned oil palm lands in Malaysia: a semi-automatic approach. International Journal of Remote Sensing 38:432-449. DOI: 10.1080/01431161.2016.1266111

Zhou F, Yu T, Du R, Fan G, Liu Y, Liu Z, Xiang J, Wang Y, Song B, Gu X, Guan L, Wei Y, Li H, Wu X, Xu J, Tu S, Zhang Y, Chen H, Cao B. 2020. Clinical course and risk factors for mortality of adult inpatients with COVID-19 in Wuhan, China: a retrospective cohort study. The Lancet 395:1054-1062. DOI: 10.1016/S0140-6736(20)30566-3 


\section{Figure 1}

Summary illustration of key points and linkages regarding the potential for future EID emergence from tropical peatlands, and potential threats to tropical peatland conservation and local communities from the current COVID-19 pandemic.

Box outline and fill colours indicate contents corresponding to labels of the three circles. Dashes indicate pre-existing factors or factors arising from the COVID-19 that impact upon solid boxes. Shaded boxes indicate potential major ultimate impacts, which as implied by the three circles are closely linked and thus potentially mutually reinforcing. See text for further details, explanations and discussion of additional points and linkages omitted here for reasons of space. Photo credits: Sara Thornon (tropical peat-swamp forest), Susan Page (peatland communities \& livelihoods) and Philippa Steinberg for the Innovative Genomics Institute (EIDs / COVID-19: Steinberg, 2020).

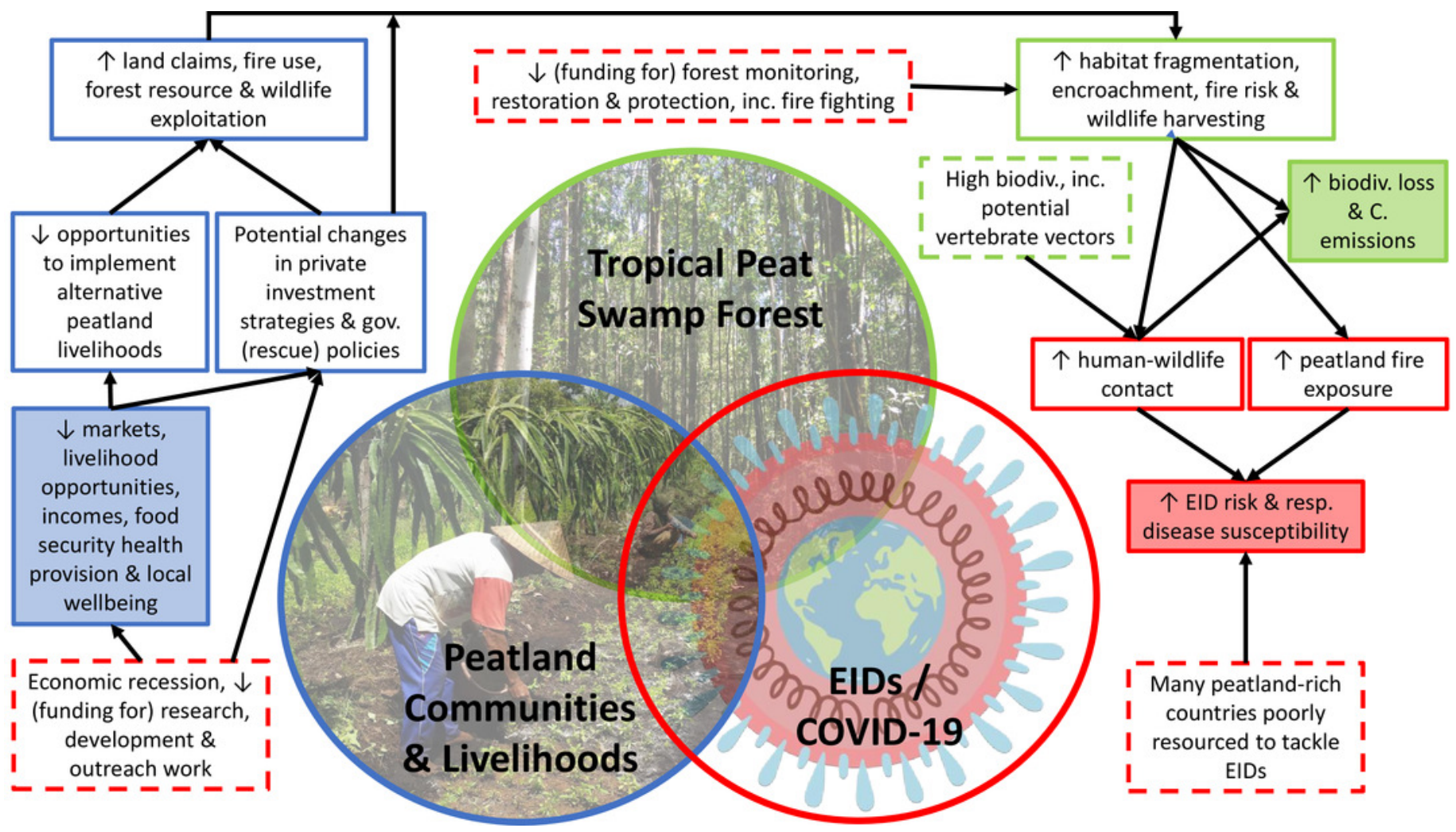




\section{Figure 2}

Map of tropical and subtropical peatlands (a) following Leifeld \& Menicetti (2018), with close-ups of the Congo Basin (b) and Riau province, Sumatra, Indonesia (c).

In (b) and (c) the satellite image is a false colour composite of Landsat 7 and 8 imagery from 2016 to 2017 created in GoogleEarth Engine. Human population density per square kilometre (Gaughan et al., 2013; Linard et al., 2012; WorldPop, 2020), is overlaid with colours ranging from pink with a density of one person per square kilometre to greater than 50 in red. Peatland boundaries are indicated by yellow lines and purple indicates treeless areas. Most of the Congo Basin peatlands have low population density, but there is Mbandaka city in the centre (red), plus a growing population in the periphery on the northeast and east. In Riau, there are large population centres, plus growing populations and plantations directly adjacent to the peatlands. Map data: Google, USGS;Gaughanet al., (2013); Linardet al. (2012); Leifeld \& Menicetti (2018); WorldPop (2020). 

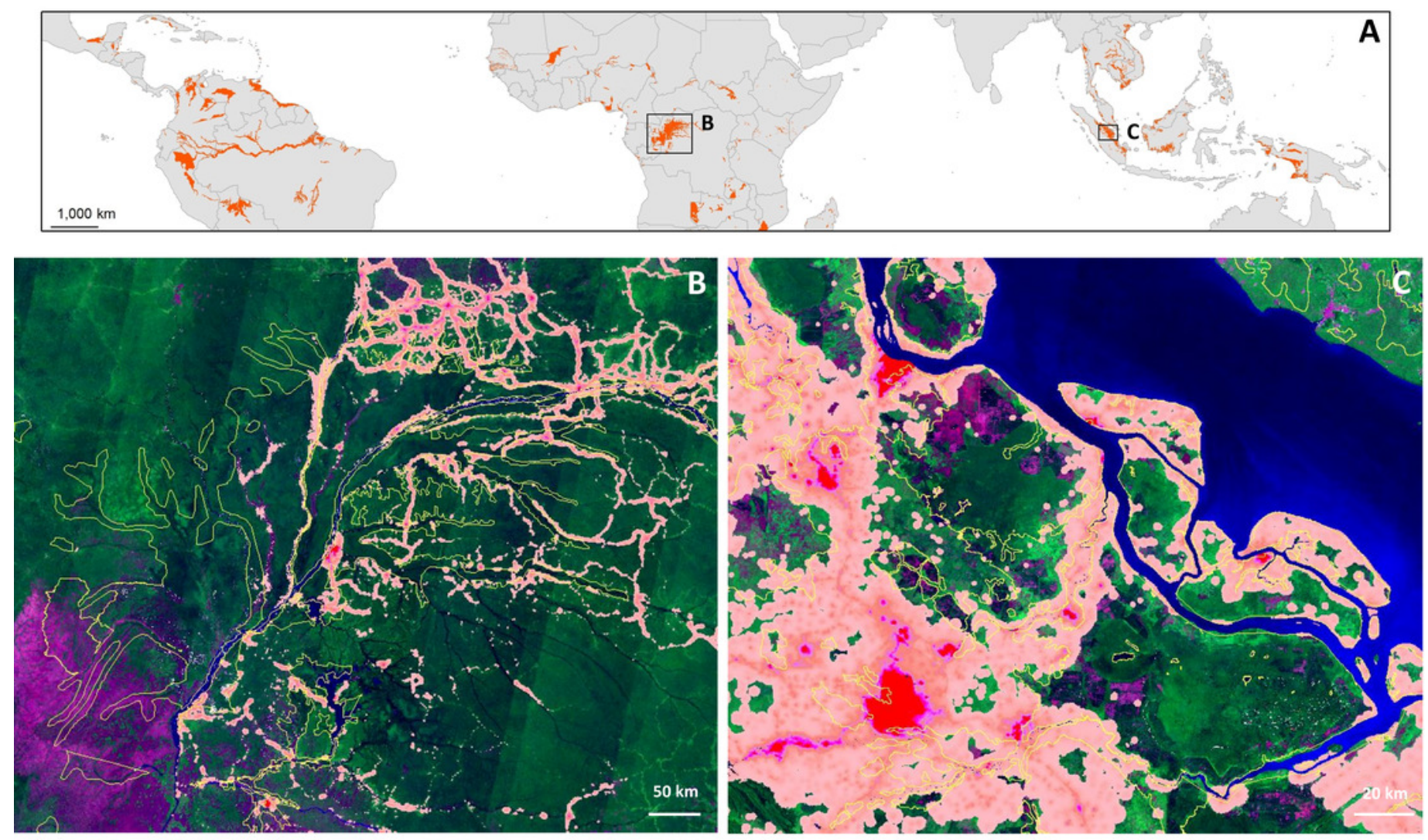


\section{Figure 3}

Figure 3. A remote tropical peatland community in Buenos Aires (a), within the Pacaya Samiria National Reserve, Peruvian Amazon, which is accessible only by boat.

People living here and in neighbouring communities rely heavily on resources extracted from the surrounding peat-forming Mauritia flexuosa palm swamps. Urarina indigenous groups living in peat-rich areas, harvest palm leaves from which to make textiles (b); important both practically and culturally for these isolated communities. The palms also offer plentiful food for wild fauna and thus the palm swamps in which they grow are important hunting spaces for people, providing bushmeat in locations far from the nearest market. Photo credits: Lydia Cole.

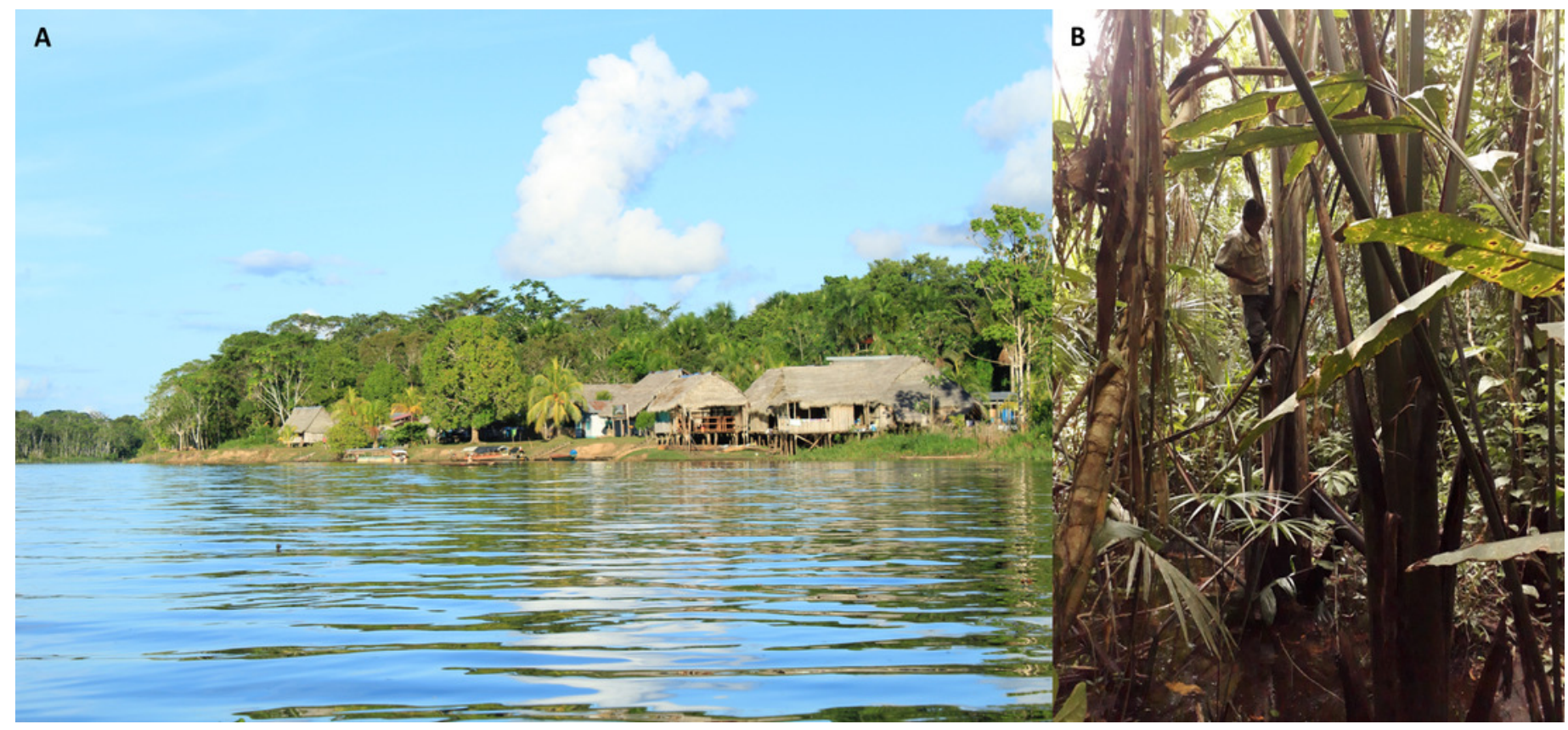




\section{Figure 4}

Figure 4. Peatland fire encroaching into forest (a) and local fishers working under thick haze conditions from peatland fires (b) in Central Kalimantan, Indonesia.

Note in (a) the immediate fire damage to the forest on the top side, and older fire damage on the bottom side, of the river. Photo credits: (a) Markurius Sera/Borneo Nature Foundation Indonesia and (b) Suzanne Turnock/Borneo Nature Foundation Indonesia.

A

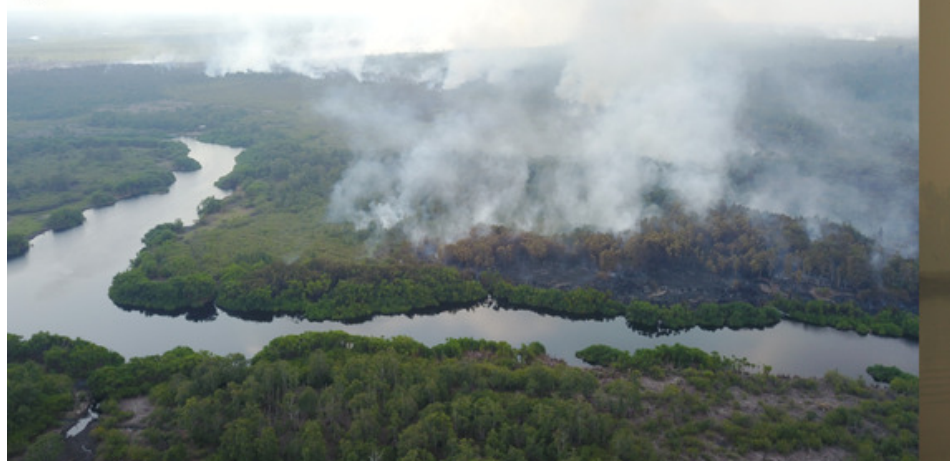

B 